Check for updates

Cite this: RSC Adv., 2017, 7, 54706

\title{
Thiocarbamoyl in synthesis of the absorbent bis- mono and dimethine cyanine dyes incorporating porphyrin, thiazoles, thiazolones, thiadiazoles, pyrazoles and pyrazolones $\uparrow$
}

\begin{abstract}
Rasha E. El-Mekawy (D) $\neq^{a}$ and A. A. Fadda (D)*b
In this study, we have introduced an outlook dealing with synthetic heteroarenium-substituted pyridines 1 that are suitable as starting materials for the synthesis of a potential new thiocarbamoyl derivative 3 that may be of value in preparative organic and biological chemistry. Herein, a new series of twelve bis-mono and dimethine cyanine dyes incorporating different heterocyclic compounds were designed by efficient and simple reaction of compound 3 with various organic reagents to overcome the obstacles of energetic reactions, because they took long times. Moreover, the electronic behaviors of these compounds were studied because of their significant activity in many medical and other fields. The photosensitizers were elucidated by spectral and analytical analyses.
\end{abstract}

Received 12th September 2017 Accepted 12th November 2017

DOI: 10.1039/c7ra10165a

rsc.li/rsc-advances

dimethine cyanines are synthesized by heating a mixture of aromatic aldehydes, a quaternary ammonium salt with an active methyl group and a catalyst agent in an organic environment under reflux. ${ }^{16}$ This synthesis has intrinsic obstacles as relatively the reaction requires relatively energetic conditions, namely heating with reflux reactants for diverse hours in solvents, many organic solvents inimical to environment and complexity in product isolation. Here, we record our feedback about some efficacious steps for the synthesis of novel hemimethine, bis-hemimethine and bismethine cyanine dyes incorporating porphyrin, substituted thiazoles, thiazolones, thiadiazoles, pyrazoles and pyrazolones. evolution of heterocyclic chemistry and are extensively used as beneficial synthons incorporating $-\mathrm{N}=\mathrm{C}=\mathrm{S}$ moiety in organic synthesis. ${ }^{2-5}$ Additionally, for the last several years, there has been considerable progress ${ }^{6,7}$ in the synthesis and applications of methine cyanine dyes, which are among the most influential functional organic dyes. They have been used as photographic sensitizers, ${ }^{8}$ optical recording materials in laser disks ${ }^{9}$ and sensitizers in photovoltaic cells. ${ }^{10}$ With the growth of relative technologies, methine cyanine dyes have been screened as tools in photodynamic treatment ${ }^{11}$ and as fluorescent labels, micelles, organelles and probes for cells. ${ }^{12-15}$ Usually, mono and

${ }^{a}$ Department of Petrochemicals, Egyptian Petroleum Research Institute, Nasr City, Cairo, Egypt

${ }^{b}$ Department of Chemistry, Faculty of Science, Mansoura University, Mansoura, Egypt. E-mail: afadda50@yahoo.com

$\dagger$ Electronic supplementary information (ESI) available. See DOI: 10.1039/c7ra10165a

\$. Present address: Department of Chemistry, Faculty of Applied Science, Umm Al-Qura University, Makkah Al Mukarrama, Saudi Arabia.

\section{Results and discussion}

We were heedful in constructing heterocycles established on thiocarbamoyl moieties such as N-substituted thiazole, thiadiazoles, pyrazole, thiophene and thiadiazoles. Even heterocyclic compounds incorporating thiocarbamoyl moieties have rarely been stated in the research field of drug construction through synthesis of solid phase. ${ }^{17-22}$ In the light of the above facts, we have developed a straightforward and efficient mode for the production of bis-thiocarbamoyl intermediate 3 . The methods are operationally simple and do not require strict conditions. The base-promoted reaction of two moles of phenyl isothiocyanate and active methylene of 2-benzyl-1-(4bromocyclohexy)pyridine-1-ium salt (1) was synthesized by heating benzylpyridine with an appropriate amount of 1,4dibromocyclohexane in refluxing toluene in $85 \%$ yield (Scheme 1). The latter reaction was performed in the existence of a catalytic quantity of potassium hydroxide in DMF and yielded the 


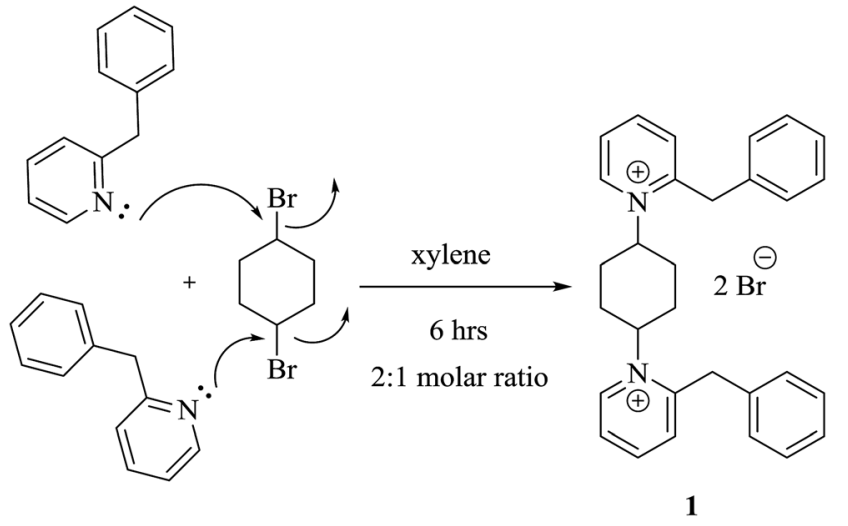

Scheme 1 New features of bis-pyridinium salt 1.

non-separated intermediate 2 , which underwent in situ neutralization with dilute $\mathrm{HCl}$, resulting in the formation of a red acyclic intermediate $\mathbf{3}$. On the other hand, $\mathbf{1}$ was refluxed with two moles of phenyl isothiocyanate for $4 \mathrm{~h}$ in absolute ethanol and fresh pellets of potassium hydroxide afforded a selfsame compound in all elemental and spectral behaviours (IR, ${ }^{1} \mathrm{H}-\mathrm{NMR},{ }^{13} \mathrm{C}-\mathrm{NMR}$, mass spectroscopy and m.p.) with the acyclic intermediate 3 (Scheme 2). Assignment of compound 3 is based on its analytical and spectral data. Infrared spectrum showed absorption bands at $v=3321$ and $2231 \mathrm{~cm}^{-1}$, attributable to two NH and two SH function groups. Moreover, IR spectrum displayed no absorption bands at $1284 \mathrm{~cm}^{-1}$ related to the absence of two $\mathrm{S}=\mathrm{O}$ function groups. This is evidence of the formation of tautomeric structure 3 and not 4 and/or $\mathbf{5}$. Also, the structure of 3 was inferred by ${ }^{1} \mathrm{H}-\mathrm{NMR}$ spectroscopy, which revealed a chemical shift $(\delta)$ at $2.27 \mathrm{ppm}$ as pentet signals corresponding to two methine protons of $\mathrm{CH}-\mathrm{N}^{+}$of the cyclohexyl ring and singlet signal at $\delta 2.17 \mathrm{ppm}$ for two SH protons; this further confirms the formation of tautomeric structure 3 . Also, the spectrum showed doublet signals at $\delta 1.47 \mathrm{ppm}$, attributable to $4 \mathrm{CH}_{2} \mathrm{CH}-\mathrm{N}^{+}$protons, in addition to $\mathrm{D}_{2} \mathrm{O}$ exchangeable protons as singlet signal at $\delta 11.2 \mathrm{ppm}$ due to two $\mathrm{NH}$ protons. The mass spectrum of structure 3 agreed with the molecular structure at $m / z=690\left(\mathrm{M}^{+},-2 \mathrm{Br}, 92 \%\right)$ with respect to the molecular formula $\mathrm{C}_{44} \mathrm{H}_{42} \mathrm{~N}_{4} \mathrm{~S}_{2} \mathrm{Br}_{2}$.

There has been particular emphasis on the synthesis of equipotent five and six heterocycles incorporating sulfur and nitrogen atoms in recent decades due to their virtual possibilities for architectural design of significant methine cyanine dyes. Consequently, the non-isolable intermediate 2 and acyclic intermediate 3 act as liaison to prepare bis-methine cyanine dye 7 bearing two pyridinium salts binding to two thiazolidinone rings via methine bridge. Furthermore, ethyl bromoacetate was added dropwise with in situ stirring to non-isolable intermediate 2 to afford $1,1^{\prime}$ (cyclohexane-1,4-diyl)bis(2-((Z)-4-oxo-1(phenyl-3-phenylthiazolidin-2-ylidene)methyl)pyridine-1-ium) dibromide (7). Alternatively, the isolated compound 3 reacted with ethyl bromoacetate in $N, N$-dimethylformamide and in the presence of freshly fused potassium carbonate in $1: 2$ molar ratio to form compound 7 . Thus, a new bis-dimethine cyanine dye 6 was synthesized via stirring of non-isolable thiocarbamoyl 2 and/or isolable thiocarbamoyl 3 with two moles of ethyl bromoacetate overnight; then the reaction mixture was acidified, giving the same chemical structure as compound 6 (Scheme 3). Bis-dimethine cyanine dye $\mathbf{6}$ was refluxed in the presence of a few drops of triethylamine in $\mathrm{N}, \mathrm{N}$-dimethylformamide and then cyclized to thiazolidinone derivative 7 , which was identical in all respects with compound 7 (IR, ${ }^{1} \mathrm{H}-\mathrm{NMR},{ }^{13} \mathrm{C}-\mathrm{NMR}$, mass spectroscopy and m.p.).

The skeleton of chemical structure 6 was promoted by its spectral and analytical analyses. Noticeably, the IR spectrum of the synthesized compound revealed absorption bands at $v=$ 1730 and $3322 \mathrm{~cm}^{-1}$, owing to two $-\mathrm{C}=\mathrm{O}$ and two $\mathrm{NH}$ functional groups, respectively. Its ${ }^{1} \mathrm{H}-\mathrm{NMR}$ spectrum exhibited distinctive triplet signals at $\delta=1.30 \mathrm{ppm}$, a singlet signal at $3.23 \mathrm{ppm}$ and quartet signals at $4.30 \mathrm{ppm}$, corresponding to two

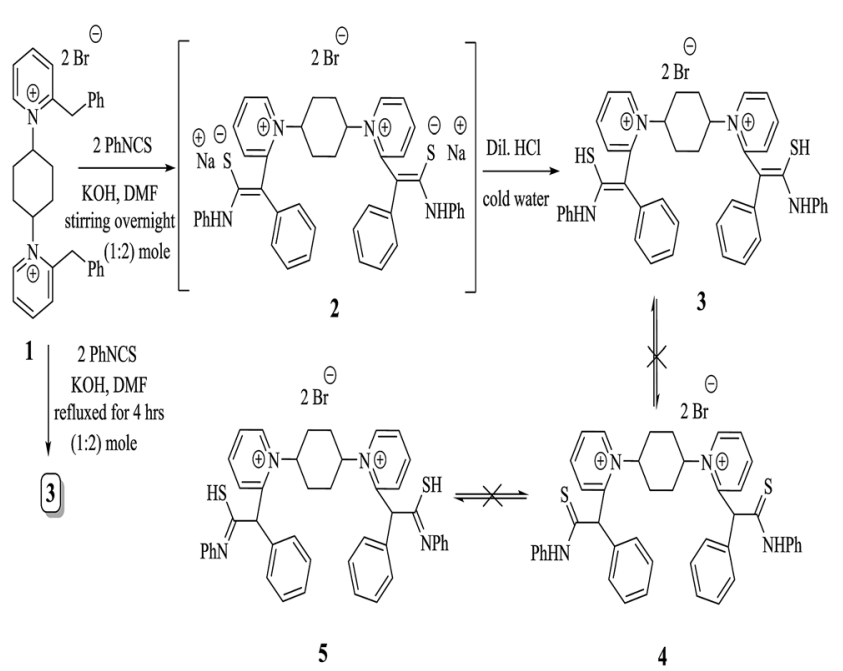

Scheme 2 Synthesis of 1,1'-[(cyclohexan-1,4-diyl)bis(2-(Z)-2-mercapto-1-phenyl-2-(phenylamino)vinyl)]bis-pyridinium dibromide (3).

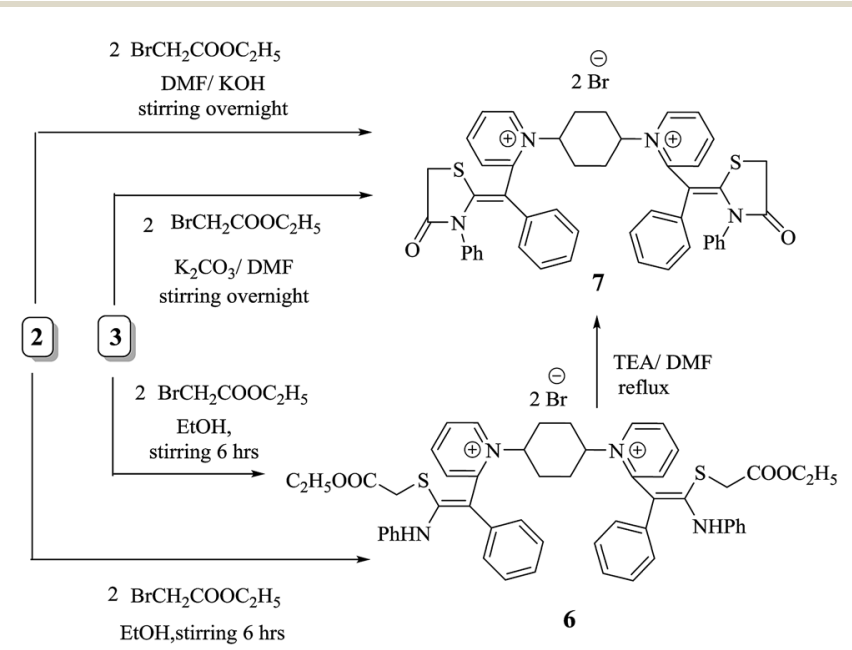

Scheme 3 Alternative synthesis of 1,1'-[(cyclohexan-1,4-diyl)bis(2((Z)-4-oxo-3-phenylthiazolidin-2-ylidene)(phenyl)methyl)]bis-pyridinium dibromide (7). 
$\mathrm{CH}_{3}-\mathrm{CH}_{2}-$, two $\mathrm{CH}_{2} \mathrm{COO}$ and two $\mathrm{CH}_{3}-\mathrm{CH}_{2}-$, respectively. On the other hand, a broad singlet band was located at $\delta=$ $12.90 \mathrm{ppm}$, assignable for two NH protons. Structure of 7 was further confirmed by ${ }^{1} \mathrm{H}-\mathrm{NMR}$, which displayed no triplet, quartet, and singlet signals at $\delta=1.30,4.30$ and $12.90 \mathrm{ppm}$ because of two $\mathrm{CH}_{3}$, two $\mathrm{CH}_{2}$ of ethoxy groups and two $\mathrm{NH}$ groups, which were involved in the reaction forming cyclized thiazolidinone ring. Thus, a singlet signal appeared at $\delta=3.12 \mathrm{ppm}$ on account of two protons related to the $\mathrm{CH}_{2}$ group. In addition, the UV-vis spectra showed $\lambda_{\max }$ at $524 \mathrm{~nm}$ and $\lambda_{\mathrm{em}}$ at $530 \mathrm{~nm}$.

Moreover, chalcones have played a definitive role in the evolution of heterocyclic compound theory. Also, they are applied extensively in organic composition..$^{23,24} \mathrm{~A}$ lot of efforts have been devoted to synthesize bis-porphyrinodimethine cyanine dye 8 by reaction of compound 7 with two moles of 1formyl porphyrin in $N, N$-dimethylformamide in the presence of a catalytic quantity of piperidine under nitrogen gas for $24 \mathrm{~h}$, affording a good yield. Structure of $\mathbf{8}$ was based on it spectral and analytical analyses. The IR spectrum showed no characteristic absorption band at $v=1732 \mathrm{~cm}^{-1}$, attributable to formyl group of porphyrin structure, and this gave an evidence that the functional group was consumed in the reaction, forming arylidene as bis-dimethine cyanine dye $8 .{ }^{1} \mathrm{H}-\mathrm{NMR}$ spectrum disclosed doublet signals at $\delta=1.41 \mathrm{ppm}$ due to $4 \mathrm{CH}_{2}$ molecules of cyclohexyl ring, six singlet signals at $\delta=4.30,6.98,6.46,6.66$, 5.62 , and $12.89 \mathrm{ppm}$ corresponding to $8 \mathrm{CH}$ groups of methine bridge of porphyrin skeleton protons, $2 \underline{\mathrm{CH}}$ methine protons of pyrrole ring of porphyrin, arylidine moiety (porphyrin $-\underline{\mathrm{CH}}=\mathrm{C}-$ ) and two $\mathrm{D}_{2} \mathrm{O}$ exchangeable protons of four $\mathrm{NH}$ groups of pyrrole rings of porphyrin. Furthermore, mass spectrometry showed molecular ion peak at $m / z=1413$ $\left(\mathrm{M}^{+}+2,-2 \mathrm{Br}, 67 \%\right)$ related to the molecular formula $\mathrm{C}_{90} \mathrm{H}_{66}{ }^{-}$ $\mathrm{N}_{12} \mathrm{O}_{5} \mathrm{~S}_{2} \mathrm{Br}_{2} .{ }^{13} \mathrm{C}$-NMR spectrum showed additional confirmation of bis-porphyrinodimethine cyanine dye 8. The UV-vis spectra displayed two interesting and strong absorption bands for $\lambda_{\max }$ at $422 \mathrm{~nm}$ and $\lambda_{\mathrm{em}}$ at $429 \mathrm{~nm}$ with respect to a soret band (B band) of porphyrin structure and $\lambda_{\max }$ at $576 \mathrm{~nm}$ and $\lambda_{\mathrm{em}}$ at $582 \mathrm{~nm}$ corresponding to dimethinecyanine dye (Scheme 4).

In a similar manner, treating the key intermediate 3 with phenacyl bromide in DMF and in the presence of a catalytic quantity of freshly fused potassium carbonate gave a single product that has been analyzed correctly for $\mathrm{C}_{60} \mathrm{H}_{50} \mathrm{~N}_{4} \mathrm{~S}_{2} \mathrm{Br}_{2}(\mathbf{1 0})$. An alternative synthesis of compound $\mathbf{1 0}$ readily occurred by treatment of non-isolable intermediate 2 with phenacyl bromide forming, a compound identical to compound $\mathbf{1 0}$ in all respects (IR, ${ }^{1} \mathrm{H}-\mathrm{NMR},{ }^{13} \mathrm{C}-\mathrm{NMR}$, mass spectroscopy and m.p.). During our approach, the formation of novel dimethine cyanine dye $\mathbf{9}$ was achieved by stirring non-isolable intermediate 2 in basic medium KOH/DMF with alcoholic solution of two moles of phenacyl bromide at room temperature for about $6 \mathrm{~h}$. Subsequently, alkylation of compound 3 with two moles of phenacyl bromide readily led to the formation of a chemical structure identical to compound $\mathbf{9}$, which underwent cyclization with a strong base such as triethylamine in DMF at $150{ }^{\circ} \mathrm{C}$ to provide $1,1^{\prime}$-(cyclohexane-1,4-diyl)bis(2-(Z)-(3,4-diphenylthiazol-

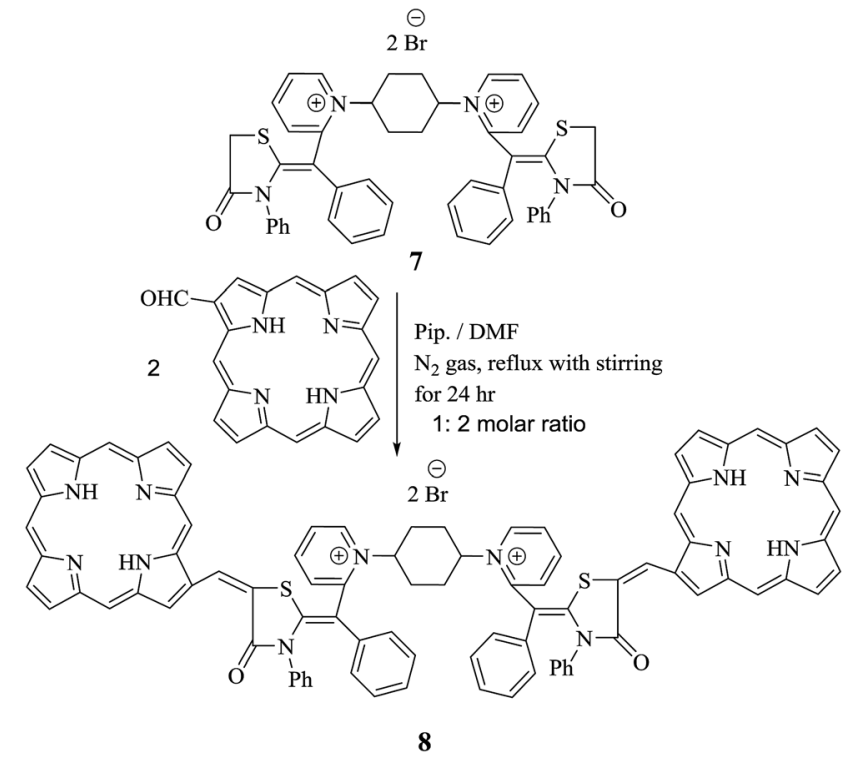

Scheme 4 Synthesis of bis-dimethine cyanine dye incorporating porphyrin moiety 8 .

2(3H)ylidene)(phenyl)methyl)-bis-pyridin-1-ium dibromide (10) in $75 \%$ yield via loss of $\mathrm{H}_{2} \mathrm{O}$ molecule (Scheme 5).

Structure 9 is proposed for the reaction output based on both atomic and spectral analyses. The IR spectroscopy showed significant absorption bands at $v=3323$ and $1728 \mathrm{~cm}^{-1}$, attributable to two $\mathrm{NH}$ groups and carbonyl group of 2 $\mathrm{Ph}-\mathrm{C}=\mathrm{O}$, respectively. On the other hand, structure 9 was assigned on the basis of ${ }^{1} \mathrm{H}-\mathrm{NMR}$ spectra, which showed a chemical shift $(\delta)$ at 2.51 and $11.92 \mathrm{ppm}$ as two singlet signals due to two $-\underline{\mathrm{CH}_{2}}-\mathrm{COPh}$ and two $\mathrm{NH}$ protons, respectively. The mass spectroscopy gave additional information on compound 9, which showed a molecular ion peak at $m / z=927$

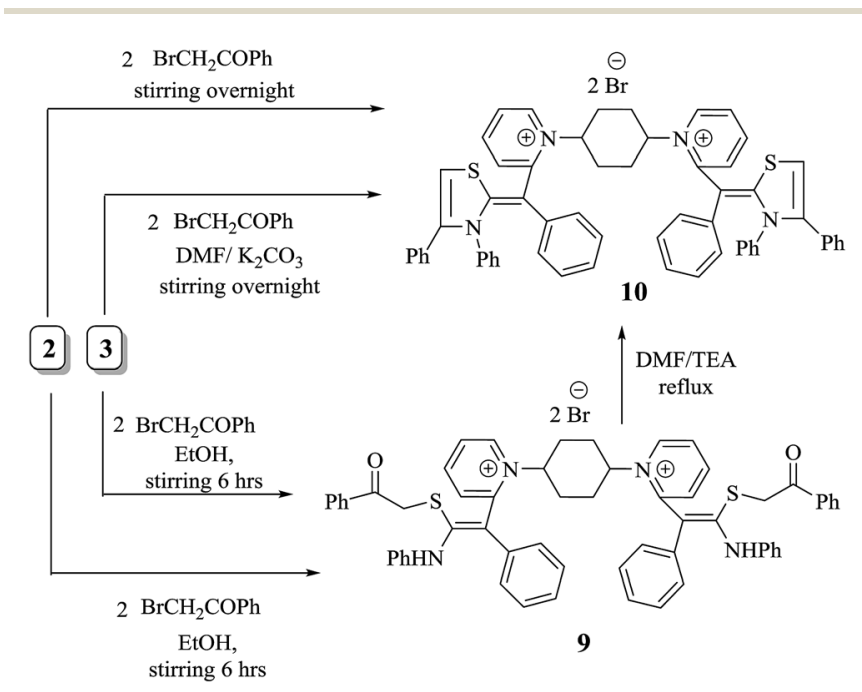

Scheme 5 Novel 1,1'-[(cyclohexane-1,4-diyl)bis(2-(Z)-(3,4-diphenylthiazol-2(3H)ylidene)(phenyl)methyl)]-bis-pyridinium dibromide (10). 
$\left(\mathrm{M}^{+},-2 \mathrm{Br}, 39 \%\right)$ attributed to the molecular formula $\mathrm{C}_{60} \mathrm{H}_{54} \mathrm{~N}_{2} \mathrm{O}_{2} \mathrm{~S}_{2} \mathrm{Br}_{2}$.

Treatment of thiocarbamoyl derivative 3 with anhydrous potassium carbonate in DMF at $150{ }^{\circ} \mathrm{C}$ followed by addition of two moles of three different aryl hydrazones resulted in the formation of $\mathrm{N}$-substituted thiadiazole derivatives 12a-c in moderate yields. The latter compounds were alternatively obtained via treatment of non-isolable intermediate 2 with two moles of three different aryl hydrazones, forming compounds with chemical behaviour identical to bis-monomethine cyanine dyes incorporating $\mathrm{N}$-substituted thiadiazole derivatives 12a-c. However, compounds 11a-c were prepared by stirring key nonisolable intermediate 2 with two moles of three different aryl hydrazones for $6 \mathrm{~h}$ at room temperature in excellent yields. Also, stirring an appropriate amount of compound 3 with different aryl hydrazones in molar ratio of $1: 2$ resulted in the formation of compounds 11a-c. Otherwise, the title compounds 11a-c were subjected to facile intramolecular cyclization by loss of aniline molecule in a basic medium $\mathrm{Et}_{3} \mathrm{~N} / \mathrm{DMF}$ to give monomethine cyanine dyes $\mathbf{1 2 a - c}$ in reasonable yields. It has been found that bis-dimethine cyanine dyes 11a-c were established on the principle of their spectral and analytical analyses. Generally, the IR showed absorption bands at $v=1695-$ $1732 \mathrm{~cm}^{-1}$ for two carbonyl groups of two benzoyl groups in each derivative, respectively. Moreover, IR exhibited characteristic absorption bands at $v=3350-3312 \mathrm{~cm}^{-1}$ on account of four NH functional groups in each compound. However, the ${ }^{1} \mathrm{H}$ NMR spectra of compound 11a showed significant singlet signals at $\delta=3.8,10.74$ and 11.61 ppm corresponding to two $-\mathrm{OCH}_{3}$ in addition to four $\mathrm{NH}$ protons $(\underline{\mathrm{NH}}-\mathrm{Ph}$ and $\left.=\mathrm{N}-\underline{\mathrm{NH}}-\mathrm{C}_{6} \mathrm{H}_{4}-\mathrm{OCH}_{3}-p\right)$. Interestingly, the ${ }^{1} \mathrm{H}-\mathrm{NMR}$ spectra of compound 12a assigned the disappearance of singlet signals at $\delta=10.73$ and $11.60 \mathrm{ppm}$ as well as multiplet signals at 6.73-7.34 ppm to aromatic hydrogens ( $\mathrm{NH}-\underline{\mathrm{Ph}})$. This is an excellent fact for cyclization of 11a to 12a. The mass spectroscopy of $\mathbf{1 2 a}$ readily displayed a molecular ion peak at

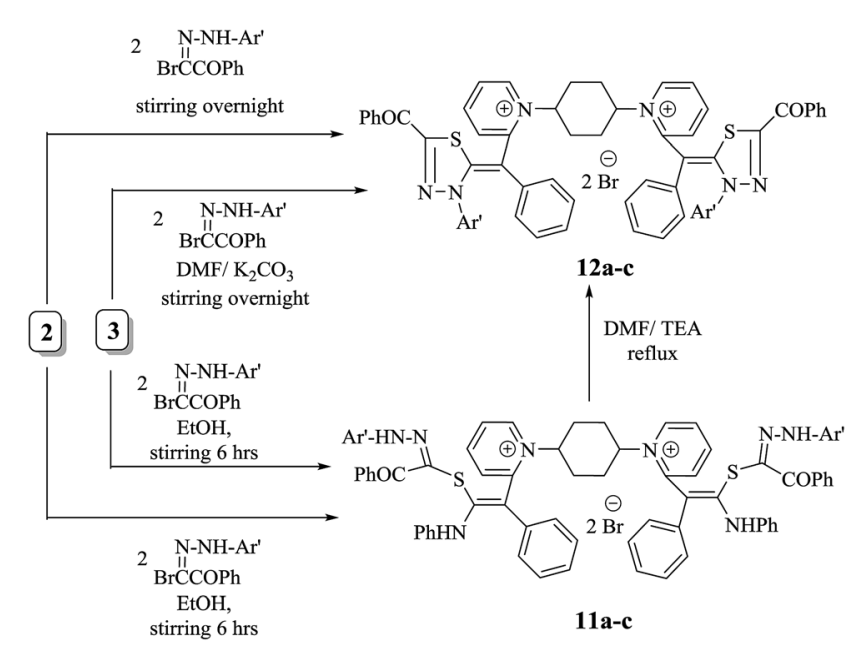

$\mathrm{Ar}=p-\mathrm{OCH}_{3}-\mathrm{C}_{6} \mathrm{H}_{5} ; p-\mathrm{CH}_{3}-\mathrm{C}_{6} \mathrm{H}_{5} ; p-\mathrm{NO}_{2}-\mathrm{C}_{6} \mathrm{H}_{5}$

Scheme 6 Novel series of monomethine cyanine dyes 12a-c. $m / z=1009\left(\mathrm{M}^{+},-2 \mathrm{Br}, 42 \%\right)$ with respect to the molecular formula $\mathrm{C}_{62} \mathrm{H}_{52} \mathrm{~N}_{6} \mathrm{O}_{4} \mathrm{~S}_{2} \mathrm{Br}_{2}$ (Scheme 6).

The finding of this category of drugs supplies a distinguished historical status of renewed drug evolution and also refers to the unpredictability of biological efficiency because of structural modulation of a prototype of pharmaceutical molecule. The broad area of curative prominence of thiocarbamoyl heterocyclic ring systems assists us to outline the synthesis of a range of new thiocarbamoyl heterocyclic derivatives incorporated in two adjacent dimethine cyanine dyes. Refluxing thiocarbamoyl derivative 3 with thiocarbohydrazide in $\mathrm{N}, \mathrm{N}$ dimethylformamide and in the presence of few drops of triethylamine produced bis-monomethine cyanine dye incorporating dithiadiazole derivative $\mathbf{1 4}$ instead of bis-monomethine cyanine dye incorporating thiadiazole derivative 13. Transformation of compound 3 into 1,1'-(cyclohexane-1,4-diyl)bis(2((Z)-2-(dihydrazinylmethyl)disulfanyl)-1-phenyl-2-(phenylamino) vinyl)pyridine-1-ium)dibromide (15) and not into 16 in good yield was achieved upon its heating with thiocarbohydrazide in absolute ethanol and in the presence of freshly fused potassium carbonate. The reaction advancement was tracked by TLC. Furthermore, treatment of $\mathbf{1 5}$ with DMF and triethylamine resulted in the cyclization of $\mathbf{1 5}$ and furnished the corresponding 1,1'-(cyclohexane-1,4-diyl)bis(2-(Z)-(5-dihydrazinyl-3-phenyl1,2,3-thiadiazol-2(3H)-ylidene(phenyl)methyl)pyridine-1-ium dibromide (14) in moderate yield, as shown in Scheme 7. The elucidation of compound $\mathbf{1 4}$ was concentrated on its spectral

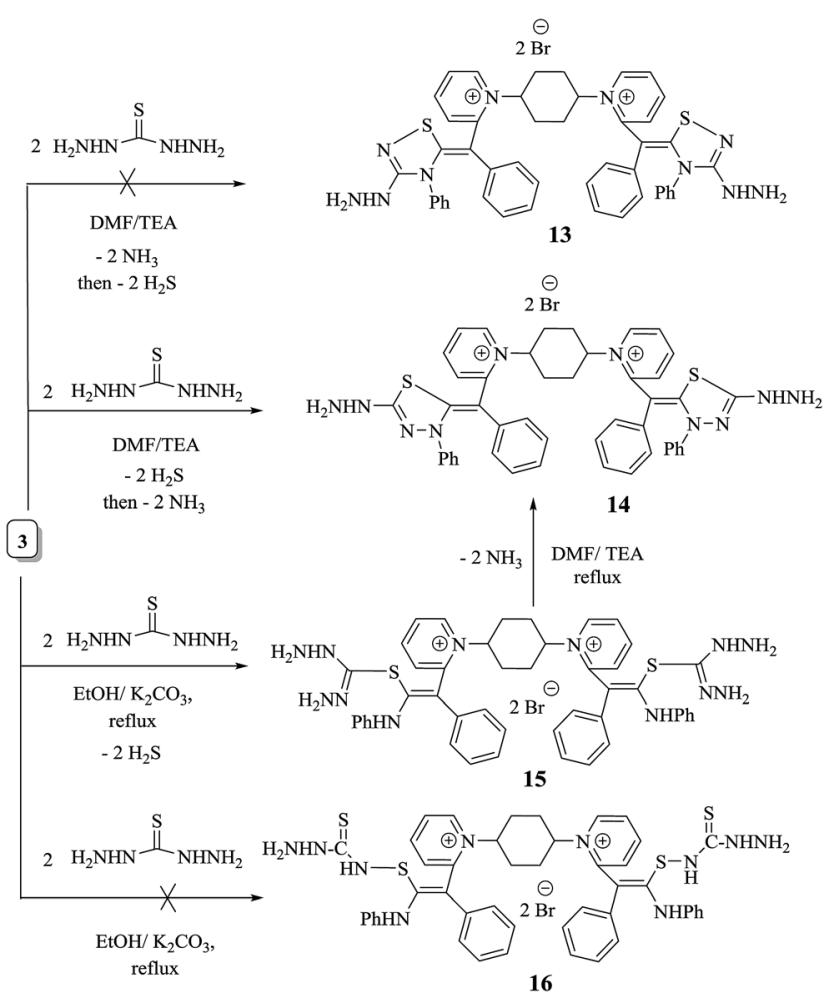

Scheme 7 Synthesis of 1,1' - [(cyclohexane-1,4-diyl)bis(2-(Z)-(5-dihydrazinyl-3-phenyl-1,2,3-thiadiazol-2(3H)-ylidene(phenyl)methyl)]bispyridinium)dibromide (14). 


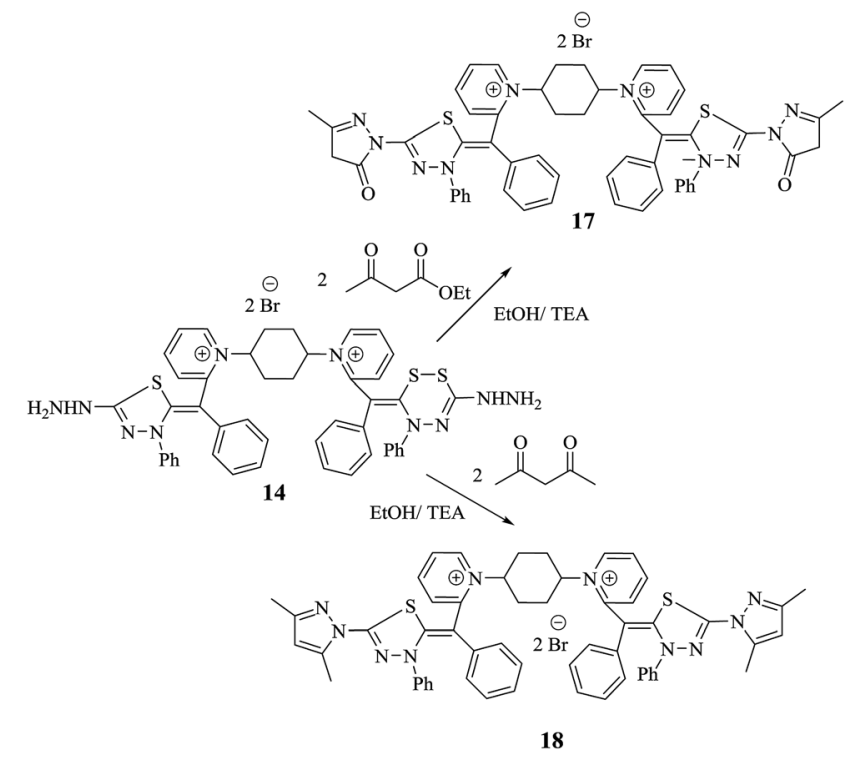

Scheme 8 New features of bis-dimethine cyanine dyes incorporated pyrazolone and pyrazole derivatives 17 and 18 .

and analytical data. The IR spectrum presented strong absorption bands at $v=3325-3174 \mathrm{~cm}^{-1}$ for two $-\underline{\mathrm{NHNH}_{2}}$ groups. However, ${ }^{1} \mathrm{H}-\mathrm{NMR}$ spectra revealed two $\overline{\text { singlet }}$ signals at 3.8 and $8.8 \mathrm{ppm}$, corresponding to $\mathrm{D}_{2} \mathrm{O}$ exchangeable protons of two $\mathrm{NH}^{\mathrm{NH}_{2}}$ and $\underline{\mathrm{NH}} \mathrm{NH}_{2}$ groups, respectively.

When compound $\mathbf{1 4}$ was subjected to heating in absolute ethanol at reflux and in the presence of triethylamine with ethyl acetoacetate and acetylacetone, single products 17 and 18 were for formed, respectively. Also, the reaction mixture was analyzed by TLC (Scheme 8). The elemental analyses and mass spectrum of the obtained products were in accordance with the molecular formula $\mathrm{C}_{54} \mathrm{H}_{48} \mathrm{~N}_{10} \mathrm{~S}_{4} \mathrm{Br}_{2}$ and $\mathrm{C}_{56} \mathrm{H}_{52} \mathrm{~N}_{10} \mathrm{~S}_{4} \mathrm{Br}_{2}$. Structure of 17 was established on the principle of its correct spectral and analytical analyses. The IR spectrum presented absorption bands at $v=1652 \mathrm{~cm}^{-1}$ for two amidic carbonyl groups. The ${ }^{1} \mathrm{H}$ NMR spectrum showed two characteristic singlet signals at $\delta=$ 1.94 and $3.02 \mathrm{ppm}$, corresponding to two $\mathrm{CH}_{3}$ and two $-\mathrm{CH}_{2} \mathrm{CO}-\mathrm{N}$ - protons, respectively, while mass spectroscopy displayed a molecular ion peak at $m / z=997\left(\mathrm{M}^{+},-2 \mathrm{Br}, 97 \%\right)$ based on the molecular formula $\mathrm{C}_{54} \mathrm{H}_{48} \mathrm{~N}_{10} \mathrm{~S}_{4} \mathrm{Br}_{2}$. Moreover, the UV-vis spectra presented absorption bands at $\lambda_{\max }=574 \mathrm{~nm}$ and $\lambda_{\mathrm{em}}=586 \mathrm{~nm}$, as presented in the experimental section.

\section{Studies on electronic absorption and emission spectra of synthesized photosensitizers}

Chemical modifications produce dramatic shifts in the chromophore absorption spectra, and with a longer methine chain, the fluorescence quantum yield of the dyes is reduced as compared to that with the conjugation and substitution of methine dyes. Synthetic cyanines ${ }^{25-28}$ are known to absorb between the visible and infrared regions of the electromagnetic spectrum. In addition, cyanines exhibit wide absorption bands and high. Due to these properties, cyanine dyes have been extensively employed in various applications. The electronic absorption spectra of the synthesized carbocyanine dyes exhibited absorption and emission bands at $\lambda_{\max }=468$ (490), 502 (522), 447 (462), 478 (508), 558. 430 (583) (439), 562, 436 (58) (440), 820, 438 (845) (442), 596, 428 (615) (438), 622, and 425 (642) (436). These absorption and emission bands are influenced by the nature of quaternary ammonium salt residues of heterocycles and substituent that undergo bathochromic shift and/or hypsochromic shift. Photosensitization increases as $\pi$ conjugation increases and vice versa. This nature is attributable to $\pi$-delocalization of positive charge of quaternary ammonium salt on nitrogen atoms. As conjugation increases, resonating structure and wavelength increase and excitation energy decreases.

The prolonged wavelength absorption of all studied compounds was cited between 461-572 and $525 \mathrm{~nm}$ for absorption and between 487 and $597 \mathrm{~nm}$ for emission. Also, their molar absorptivity values were between 4.46 and 4.56

Table 1 Electronic absorption and emission spectra of newly prepared efficient drugs 3, 6, 7, 8, 9, 10, 11, 12, 14, 15, 17 and 18

\begin{tabular}{|c|c|c|c|c|c|}
\hline $\begin{array}{l}\text { Compound } \\
\text { no. }\end{array}$ & $\begin{array}{l}\text { Absorption bands } \\
\lambda_{\max }(\mathrm{nm})\end{array}$ & $\begin{array}{l}\text { Emission bands } \\
\lambda_{\text {em }}(\mathrm{nm})\end{array}$ & $\begin{array}{l}\text { Molar absorptivity } \\
\log \varepsilon\left(\mathrm{L} \mathrm{mol}^{-1} \mathrm{~cm}^{-1}\right)\end{array}$ & $\begin{array}{l}\text { Stoke shift } \\
\lambda_{\max }-\lambda_{\text {em }}\end{array}$ & Quantum yield $(Q)$ \\
\hline 3 & 461 & 487 & 4.46 & 26 & 1.06 \\
\hline 6 & 485 & 492 & 4.48 & 7 & 1.01 \\
\hline 7 & 524 & 530 & 4.51 & 6 & 1.01 \\
\hline 8 & $422(576)$ & $429(582)$ & $4.52(4.73)$ & $7(6)$ & $1.02(1.010)$ \\
\hline 9 & 486 & 495 & 4.48 & 9 & 1.06 \\
\hline 10 & 525 & 533 & 4.52 & 9 & 1.02 \\
\hline $11 a$ & 490 & 501 & 4.48 & 11 & 1.02 \\
\hline $11 b$ & 491 & 506 & 4.49 & 15 & 1.03 \\
\hline $11 \mathrm{c}$ & 496 & 508 & 4.49 & 12 & 1.02 \\
\hline $12 a$ & 526 & 534 & 4.51 & 8 & 1.02 \\
\hline $12 b$ & 528 & 536 & 4.52 & 8 & 1.01 \\
\hline $12 \mathrm{c}$ & 532 & 536 & 4.52 & 4 & 1.01 \\
\hline 14 & 546 & 557 & 4.53 & 11 & 1.02 \\
\hline 15 & 513 & 532 & 4.50 & 19 & 1.03 \\
\hline 17 & 570 & 597 & 4.55 & 27 & 1.04 \\
\hline 18 & 572 & 589 & 4.56 & 17 & 1.03 \\
\hline
\end{tabular}


$\mathrm{L} \mathrm{M}^{-1} \mathrm{~cm}^{-1}$ (Table 1). The latter values are linked to the bathochromic and hypsochromic shifts, which affect the longest wavelength absorption band and indicate that the dye is accommodated into the potholes of the double helix. ${ }^{29}$ Notably, the absorption bands increase according to increasing $\pi$-delocalization of positive charge of heteroarenium nitrogen atoms due to increasing resonating structure, leading to more stable and low energy molecules, as shown in Table 1. It is well known that the conjugated system undergoes photosensitization by enough quanta, which leads to excitation of bonding electrons and unpaired electrons, giving possible electronic transitions such as $\sigma-\sigma^{*}, \mathrm{n}-\pi^{*}$ and $\pi-\pi^{*}$. This may confirm the later mentioned facts. Compound 8 revealed two characteristic bands at $\lambda_{\max }=422$ and $582 \mathrm{~nm}$ related to soret bands of two highly extended conjugated porphyrin systems and absorption bands of bis-dimethine cyanine dyes. This means that structure 8 shows a larger bathochromic shift (red shift) than other compounds and high intensity due to high resonating positive charge across the system. It was observed that cyanine dyes linked with heterocyclic rings incorporating more heteroatoms revealed bathochromic shift as follows: by comparing all synthesized compounds: $7>6,8>7,10>9,12 a-c>11 a-c, 14>$ 15 and $17>18$. All of these correspond to $\pi$-delocalization of the chromophore bis-methine cyanine dyes; as conjugation increases, resonating structure and wavelength increase and excitation energy decreases. In conclusion, we have developed an unprecedented, original two-component, one-pot approach for the synthesis of highly substituted methine cyanine dyes 3 , $6,7,8,9,10,11,12,14,15,17$ and 18 via a non-isolable intermediate $\mathbf{2}$ and/or a key thiocarbamoyl intermediate $\mathbf{3}$ in moderate to high yield. The chemical structures of the obtained potent and selective drugs are analysed by IR, ${ }^{1} \mathrm{H}-\mathrm{NMR},{ }^{13} \mathrm{C}$ NMR, mass spectroscopy, UV-vis spectroscopy and elemental analyses for $\mathrm{C} \mathrm{H} \mathrm{N}$ element.

\section{Experimental}

Melting degrees were uncorrected in degree centigrade and tested on a Gallenkamp electric melting point instrument. The infrared (IR) spectra were detected (KBr disk) on a Mattson 5000 FTIR spectrometer, the ${ }^{1} \mathrm{H}-\mathrm{NMR}$ and ${ }^{13} \mathrm{C}-\mathrm{NMR}$ spectra were obtained on a Bruker WPSY $200 \mathrm{MHz}$ spectrometer with TMS as an interior standard and the chemical shifts were in $\delta \mathrm{ppm}$ using (DMSO- $d_{6}$ ) and/or $\mathrm{CDCl}_{3}$ as solvents and recorder at the Faculty of Science, Mansoura University, Egypt. Mass spectroscopy was performed at $70 \mathrm{eV}$ using Varian MAT 311 and elemental analyses (C, H and N) were conducted at the Microanalytical Center, Faculty of Science, Cairo University. The outcomes were got in a kindly approval $( \pm 0.03)$ with the studied rates.

\section{Synthesis}

1,1'-(Cyclohexan-1,4-diyl)bis(2-benzylpyridinium) (1). In a round bottom flask equipped with dean-stark apparatus, a mixture of 2-benzylpyridine (0.02 mol, $3.38 \mathrm{gm})$ and 1,4dibromocyclohexane (0.01 mol, $2.42 \mathrm{gm})$ was heated under reflux in dry xylene for $4 \mathrm{~h}$. The reaction mixture was observed by thin layer chromatography (TLC control). The reaction mixture solution was cooled at room temperature. First, the isolated product was washed with a non-polar solvent such as diethyl ether and then triturated with absolute ethanol. The solid precipitate was filtered and purified using a polar protic solvent like absolute ethanol to produce compound $\mathbf{1}$.

Yield 85\%; white needle crystals; m.p. $=163{ }^{\circ} \mathrm{C}$; IR $(\mathrm{KBr})$ : $v / \mathrm{cm}^{-1}=3081(\mathrm{Ar}-\mathrm{CH}), 2920\left(\mathrm{CH}_{2}\right), 1622(\mathrm{C}=\mathrm{N}) ;{ }^{1} \mathrm{H}-\mathrm{NMR}$ $\left(\right.$ DMSO- $\left.d_{6}\right) \delta / \mathrm{ppm}=1.39\left(\mathrm{~d}, J=5.3 \mathrm{~Hz}, 8 \mathrm{H}, 4 \mathrm{CH}_{2} \mathrm{CH}-\mathrm{N}^{+}\right)$, $2.26\left(\mathrm{~m}, J=7.2 \mathrm{~Hz}, 2 \mathrm{H}, 2 \underline{\mathrm{CH}}-\mathrm{N}^{+}\right.$of cyclohexyl ring), $3.81(\mathrm{~s}, J=$ $6.8 \mathrm{~Hz}, 4 \mathrm{H}, 2 \mathrm{CH}_{2}-\mathrm{Ph}$ ), 7.20-7.28 (m, 10H, 2Ar-H), 8.04 (d.d, $J=$ $7.0 \mathrm{~Hz}, 2 \mathrm{H}, 2 \mathrm{CH}$ of pyridinium ring), $8.52(\mathrm{~d}, J=6.2 \mathrm{~Hz}, 2 \mathrm{H}, 2 \mathrm{CH}$ of pyridinium ring), 8.56 (d.d, $J=5.8 \mathrm{~Hz}, J=4.9 \mathrm{~Hz}, 2 \mathrm{H}, 2 \mathrm{CH}$ of pyridinium ring), 8.91 (d, $J=7.0 \mathrm{~Hz}, 2 \mathrm{H}, 2 \mathrm{CH}$ of pyridinium ring); ${ }^{13} \mathrm{C}-\mathrm{NMR}$ (DMSO- $d_{6}$ ) $\delta / \mathrm{ppm}=24.4$, 39.4, 57.6, 125.4, 125.7, 126.4 128.6, 129.0, 136.2, 145.6, 151.3; MS: $(\mathrm{m} / \mathrm{z}, \%) 422$ $\left(\mathrm{M}^{+}+2,-2 \mathrm{Br}, 100 \%\right), 356$ (42\%), 332 (34\%), 255 (20\%), 241 (57\%), 213 (62\%), 185 (72\%), 158 (55\%), 117 (70\%), 76 (23\%). Anal. calcd for $\mathrm{C}_{30} \mathrm{H}_{32} \mathrm{~N}_{2} \mathrm{Br}_{2}$ (580): C, 85.67; H, 7.67; N, 6.66\%. Found: C, 85.70; H, 7.79; N, 6.65\%.

1,1'-[(Cyclohexane-1,4-diyl)bis(2-(Z)-2-mercapto-1-phenyl-2(phenylamino)vinyl)]bis-pyridinium dibromide (3). In a conical flask, a solution of 2-benzyl-1-(4-bromocyclohexy) pyridine-1-ium salt (1) (1.16 gm, $2 \mathrm{mmol})$ and two moles of phenyl isothiocyanate $(1.07 \mathrm{gm}, 4 \mathrm{mmol})$ in $N, N$-dimethylformamide and potassium hydroxide pellets $(0.56 \mathrm{gm}, 5$ $\mathrm{mmol}$ ) were stirred overnight. The reaction blend attained a pale yellow to deep yellow colour. Then, the reaction content was poured onto ice-cold water and acidify it with diluted hydrochloric acid. The resultant yellow solid was collected by filtration and washed several times with cold water. The collected solid was dried. After that, it was purified with absolute ethanol to separate compound 3 .

Yield 96\%; yellow crystals; m.p. $=196-197{ }^{\circ} \mathrm{C}$; IR (KBr): $v / \mathrm{cm}^{-1}=3321(2 \mathrm{NH}), 3009(\mathrm{Ar}-\mathrm{CH}), 2921\left(\mathrm{CH}_{2}\right), 2231(2 \mathrm{SH})$, $1598(\mathrm{C}=\mathrm{N}) ;{ }^{1} \mathrm{H}-\mathrm{NMR}\left(\mathrm{DMSO}-d_{6}\right) \delta / \mathrm{ppm}=1.40(\mathrm{~d}, J=7.2 \mathrm{~Hz}$, $\left.8 \mathrm{H}, 4 \mathrm{CH}_{2} \mathrm{CH}-\mathrm{N}^{+}\right), 2.27\left(\mathrm{~m}, J=6.1 \mathrm{~Hz}, 2 \mathrm{H}, 2 \underline{\mathrm{CH}}-\mathrm{N}^{+}\right.$of cyclohexyl ring), 2.17 (s, $J=5.0 \mathrm{~Hz}, 2 \mathrm{H}, 2 \mathrm{SH}), 7.20-7.37(\mathrm{~m}, J=$ $7.5 \mathrm{~Hz}, 20 \mathrm{H}, 4 \mathrm{Ar}-\mathrm{H}), 6.73(\mathrm{~d}, J=6.8 \mathrm{~Hz}, 2 \mathrm{H}, 2 \mathrm{CH}$ of pyridinium ring), 6.69 (d.d, $J=7.5 \mathrm{~Hz}, 2 \mathrm{H}, 2 \mathrm{CH}$ of pyridinium ring), 7.07 (d.d, $J=8.0 \mathrm{~Hz}, 2 \mathrm{H}, 2 \mathrm{CH}$ of pyridinium ring), 8.01 (d, $J=5.2 \mathrm{~Hz}$, $2 \mathrm{H}, 2 \mathrm{CH}$ of pyridinium ring), $11.20(\mathrm{~s}, 2 \mathrm{H}, 2 \mathrm{NH}) ;{ }^{13} \mathrm{C}-\mathrm{NMR}$ $\left(\right.$ DMSO- $\left.d_{6}\right) \delta / \mathrm{ppm}=24.5,58.6,125.4,114.6,119.5,122.1$, 125.7, 126.4, 128.6, 129.0, 136.2, 140.9, 145.6, 147.6, 152.3; MS: $(\mathrm{m} / \mathrm{z}, \%) 690\left(\mathrm{M}^{+},-2 \mathrm{Br}, 92 \%\right), 657$ (40\%), 624 (14\%), 533 (20\%), 443 (57\%), 366 (62\%), 290 (72\%), 278 (15\%), 266 (100\%), 188 (23\%), 110 (53\%), 82 (74\%), 54 (61\%). Anal. calcd for $\mathrm{C}_{44} \mathrm{H}_{42} \mathrm{~N}_{4} \mathrm{~S}_{2} \mathrm{Br}_{2}$ (850): C, 76.48; H, 6.13; N, 8.11\%. Found: C, $76.45 ; \mathrm{H}, 6.10 ; \mathrm{N}, 8.09 \%$.

\section{General procedure for the generation of bis-dimethine cyanine dyes 7,10 and $12 a-c$}

Pathway 1. To a cold suspension solution of potassium hydroxide (0.56 gm, $5 \mathrm{mmol})$ in DMF $(30 \mathrm{ml})$, 2-benzyl-1-(4bromocyclohexy)pyridine-1-ium salt (1.16 gm, $2 \mathrm{mmol})$ was 
added followed by two moles of phenyl isothiocyanate $(1.07 \mathrm{gm}$, $4 \mathrm{mmol}$ ) and the mixture was stirred overnight at $25{ }^{\circ} \mathrm{C}$. Next, the solution was treated by ethyl bromoacetate and/or phenacyl bromide and/or three different aryl hydrazones ( $4 \mathrm{mmol})$. The mixture was then stirred nightly at room temperature. The reaction blend was checked by the TLC plate. After that, it was poured onto ice-cold water. The reaction mixture was acidified using dilute hydrochloric acid until it gave solid products 7, 10 and 12a-c, which were filtered, washed with cold water, dried and recrystallized with aqueous ethanol to give compounds 7 , 10 and 12a-c.

Pathway 2. To a cold suspension solution of potassium carbonate $(0.69 \mathrm{gm}, 5 \mathrm{mmol})$ in DMF (30 ml), compound 3 (1.70 gm, $2 \mathrm{mmol}$ ) was added followed by treatment with two moles of ethyl bromoacetate and/or phenacyl bromide and/or three different aryl hydrazones $(4 \mathrm{mmol})$. The reaction blend was stirred nightly at chamber temperature until completion. The reaction contents were poured onto ice-cold water. Acidification of the solution via dilute $\mathrm{HCl}$ until the environment became acidic produced solid products 7, 10 and 12a-c, which were filtered, washed with cold water, dried and recrystallized with molar ratio $10: 2$ of absolute ethanol : DMF to give compounds 7, 10 and 12a-c.

Pathway 3. A solution of compounds 6, 9 and 11a-c were refluxed in $N, N$-dimethylformamide and a few drops of triethylamine. The mixture content was cooled then poured onto ice-cold water and acidify with dil. $\mathrm{HCl}$. The precipitated product was filtered. The isolated product was dried then purified with absolute ethanol to yield 7, 10 and 12a-c.

1,1'-[(Cyclohexan-1,4-diyl)bis(2-((Z)-4-oxo-3-phenylthiazolidin-2ylidene)(phenyl)methyl)]bis-pyridinium dibromide (7). Yield 52\%; red crystals; m.p. $=210-211^{\circ} \mathrm{C}$; IR $(\mathrm{KBr}): v / \mathrm{cm}^{-1}=3009(\mathrm{Ar}-\mathrm{CH})$, $2922\left(\mathrm{CH}_{2}\right), 1690(2 \mathrm{C}=\mathrm{O}), 1598(\mathrm{C}=\mathrm{N}) ;{ }^{1} \mathrm{H}-\mathrm{NMR}\left(\mathrm{DMSO}-d_{6}\right)$ $\delta / \mathrm{ppm}=1.42\left(\mathrm{~d}, J=6.1 \mathrm{~Hz}, 8 \mathrm{H}, 4 \underline{\mathrm{CH}_{2}} \mathrm{CH}-\mathrm{N}^{+}\right), 2.28(\mathrm{~m}, J=$ $7.3 \mathrm{~Hz}, 2 \mathrm{H}, 2 \underline{\mathrm{CH}}-\mathrm{N}^{+}$of cyclohexyl ring), $3.123(\mathrm{~s}, J=5.3 \mathrm{~Hz}$, $4 \mathrm{H}, 2 \mathrm{CH}_{2}$ of thiazolidinone ring), 7.21-7.47 (m, 20H, 4Ar-H), $7.79(\mathrm{~d}, J=5.9 \mathrm{~Hz}, 2 \mathrm{H}, 2 \mathrm{CH}$ of pyridinium ring), 8.01 (d.d, $J=$ $5.7 \mathrm{~Hz}, 2 \mathrm{H}, 2 \mathrm{CH}$ of pyridinium ring), 8.14 (d.d, $J=6.9 \mathrm{~Hz}, 2 \mathrm{H}$, $2 \mathrm{CH}$ of pyridinium ring), 8.56 (d, $J=7.2 \mathrm{~Hz}, 2 \mathrm{H}, 2 \mathrm{CH}$ of pyridinium ring); ${ }^{13} \mathrm{C}-\mathrm{NMR}$ (DMSO- $d_{6}$ ) $\delta / \mathrm{ppm}=22.9,24.5,59.0$, 109.5 , 122.9, 125.4, 116.6, 118.5, 123.2, 125.7, 126.4, 128.6, 129.0, 136.4, 140.9, 145.6, 147.6, 153.3. 178.9; MS: $(\mathrm{m} / \mathrm{z}, \%) 771$ $\left(\mathrm{M}^{+},-2 \mathrm{Br}^{-}, 39 \%\right), 727$ (69\%), 683 (51\%), 607 (27\%), 531 (59\%), 397 (62\%), 263 (64\%), 251 (45\%), 239 (100\%), 161 (23\%), 83 (68\%), 55 (64\%). Anal. calcd for $\mathrm{C}_{48} \mathrm{H}_{42} \mathrm{~N}_{4} \mathrm{O}_{2} \mathrm{~S}_{2} \mathrm{Br}_{2}$ (931): C, 74.78; H, 5.49; N, 7.27\%. Found: C, 74.80; H, 5.52; N, 7.29\%.

1,1'-[(Cyclohexane-1,4-diyl)bis(2-(Z)-(3,4-di-phenylthiazol-2(3H)ylidene)(phenyl)methyl)]bis-pyridinium dibromide (10). Yield 62\%; red crystals; m.p. $=240{ }^{\circ} \mathrm{C}$; IR $(\mathrm{KBr}): v / \mathrm{cm}^{-1}=3023(\mathrm{Ar}-\mathrm{CH})$, $2920\left(\mathrm{CH}_{2}\right), 1565(\mathrm{C}=\mathrm{N}) ;{ }^{1} \mathrm{H}-\mathrm{NMR}\left(\mathrm{CHCl}_{3}\right) \delta / \mathrm{ppm}=1.41(\mathrm{~d}, J$ $\left.=7.0 \mathrm{~Hz}, 8 \mathrm{H}, 4 \mathrm{CH}_{2} \mathrm{CH}-\mathrm{N}^{+}\right), 2.27(\mathrm{~m}, J=7.2 \mathrm{~Hz}, 2 \mathrm{H}$, $2 \underline{\mathrm{CH}}-\mathrm{N}^{+}$of cyclohexyl ring), $6.73(\mathrm{~s}, J=5.9 \mathrm{~Hz}, 2 \mathrm{H}, 2 \mathrm{CH}$ of thiazole ring), 7.20-7.45 (m, 20H, 4Ar-H), $7.29(\mathrm{~d}, J=8.0 \mathrm{~Hz}, 2 \mathrm{H}$, $2 \mathrm{CH}$ of pyridinium ring), 7.52-7.71 (m, 10H, $2 \mathrm{Ar}-\mathrm{H}), 8.11$ (d.d, $J$ $=7.0 \mathrm{~Hz}, 2 \mathrm{H}, 2 \mathrm{CH}$ of pyridinium ring), 8.13 (d.d, $J=5.6 \mathrm{~Hz}, 2 \mathrm{H}$, $2 \mathrm{CH}$ of pyridinium ring), $8.93(\mathrm{~d}, J=6.7 \mathrm{~Hz}, 2 \mathrm{H}, 2 \mathrm{CH}$ of pyridinium ring); ${ }^{13} \mathrm{C}-\mathrm{NMR}$ (DMSO- $d_{6}$ ) $\delta / \mathrm{ppm}=24.0,29.5,58.0$,
$106.5,110.9,122.4,127.9,128.3,128.6,129.5,132.5,133.4$, 137.6, 140.9, 145.6, 147.6, 147.9; MS: $(\mathrm{m} / \mathrm{z}, \%) 892\left(\mathrm{M}^{+}+1,-2 \mathrm{Br}^{-}\right.$, 25\%), 816 (32\%), 740 (11\%), 664 (64\%), 588 (19\%), 505 (62\%), 422 (100\%), 410 (35\%), 346 (10\%), 270 (73\%), 258 (68\%), 246 (64\%), 181 (25\%), 116 (89\%), 76 (68\%). Anal. calcd for $\mathrm{C}_{60} \mathrm{H}_{50} \mathrm{~N}_{4} \mathrm{~S}_{2} \mathrm{Br}_{2}$ (1051): C, 80.86; H, 5.66; N, 6.89\%. Found: C, 80.87; H, 5.68; N, 6.92\%.

1,1'-[(Cyclohexane-1,4-diyl)bis(2-(Z)-(5-benzoyl-3-(4-methoxyphenyl)1,3,4-thidiazol-2(3H)-ylidene)(phenyl)methyl)]bis-pyridinium dibromide (12a). Yield 39\%; brown crystals; m.p. $=230-232{ }^{\circ} \mathrm{C}$; IR $(\mathrm{KBr}): v / \mathrm{cm}^{-1}=3002(\mathrm{Ar}-\mathrm{CH}), 2922\left(\mathrm{CH}_{2}\right), 1737(\mathrm{C}=\mathrm{O}), 1568$ $(\mathrm{C}=\mathrm{N}) ;{ }^{1} \mathrm{H}-\mathrm{NMR}\left(\mathrm{CHCl}_{3}\right) \delta / \mathrm{ppm}=1.42(\mathrm{~d}, J=7.3 \mathrm{~Hz}, 8 \mathrm{H}$, $\left.4 \underline{\mathrm{CH}_{2}} \mathrm{CH}-\mathrm{N}^{+}\right), 2.27\left(\mathrm{~m}, J=5.3 \mathrm{~Hz}, 2 \mathrm{H}, 2 \underline{\mathrm{CH}}-\mathrm{N}^{+}\right.$of cyclohexyl ring), 3.81 (s, $\left.J=7.5 \mathrm{~Hz}, 6 \mathrm{H}, 2 \mathrm{OCH}_{3}\right), 7.13$ (d, $J=7.1 \mathrm{~Hz}$, $4 \mathrm{H}, \mathrm{C}-\mathrm{H}$ of $\left.\mathrm{C}_{6} \mathrm{H}_{4}-\mathrm{OCH}_{3}-p\right), 7.29$ (d, $J=7.9 \mathrm{~Hz}, 2 \mathrm{H}, 2 \mathrm{CH}$ of pyridinium ring), 7.34-7.50 (m, $J=5.4 \mathrm{~Hz}, 10 \mathrm{H}, 2 \mathrm{Ar}-\mathrm{H}), 7.52(\mathrm{~d}, J=$ $5.6 \mathrm{~Hz}, 4 \mathrm{H}, \mathrm{C}-\mathrm{H}$ of $\left.\mathrm{C}_{6} \mathrm{H}_{4}-\mathrm{OCH}_{3}-p\right)$, 7.49-7.81 (m, 10H, 2Ar- $\mathrm{H}$ ), 8.12 (d.d, $J=7.3 \mathrm{~Hz}, 2 \mathrm{H}, 2 \mathrm{CH}$ of pyridinium ring), 8.14 (d.d, $J$ $=7.0 \mathrm{~Hz}, 2 \mathrm{H}, 2 \mathrm{CH}$ of pyridinium ring), $8.90(\mathrm{~d}, J=7.5 \mathrm{~Hz}, 2 \mathrm{H}$, $2 \mathrm{CH}$ of pyridinium ring); ${ }^{13} \mathrm{C}-\mathrm{NMR}$ (DMSO- $\left.d_{6}\right) \delta / \mathrm{ppm}=24.0$, 31.2 , 55.8, 68.3, 115.1, 120.7, 122.7, 127.9, 128.3, 128.5, 137.0, 137.9, 139.0, 140.0, 148.3, 149.6, 155.3, 179.3; MS: (m/z, \%) 1009 $\left(\mathrm{M}^{+},-2 \mathrm{Br}^{-}, 75 \%\right), 933$ (47\%), 857 (18\%), 776 (64\%), 669 (59\%), 641 (32\%), 613 (17\%), 529 (65\%), 445 (100\%), 369 (23\%), 293 (46\%), 281 (16\%), 269 (81\%), 258 (68\%), 246 (64\%), 181 (25\%), 116 (89\%), 76 (68\%). Anal. calcd for $\mathrm{C}_{62} \mathrm{H}_{52} \mathrm{~N}_{6} \mathrm{O}_{4} \mathrm{~S}_{2} \mathrm{Br}_{2}$ (1169): C, 73.79; H, 5.19; N, 8.33\%. Found: C, 73.79; H, 5.19; N, 8.33\%.

1,1'-[(Cyclohexane-1,4-diyl)bis(2-(Z)-(5-benzoyl-3-(4-methylphenyl)-1,3,4-thidiazol-2(3H)-ylidene) (phenyl)methyl)]bispyridinium dibromide (12b). Yield 39\%; brown crystals; m.p. $=231-234{ }^{\circ} \mathrm{C}$; IR (KBr): $v / \mathrm{cm}^{-1}=3002(\mathrm{Ar}-\mathrm{CH}), 2922\left(\mathrm{CH}_{2}\right)$, $1737(\mathrm{C}=\mathrm{O}), 1568(\mathrm{C}=\mathrm{N}) ;{ }^{1} \mathrm{H}-\mathrm{NMR}\left(\mathrm{CHCl}_{3}\right) \delta / \mathrm{ppm}=1.42(\mathrm{~d}, J$ $\left.=6.1 \mathrm{~Hz} 8 \mathrm{H}, 4 \underline{\mathrm{CH}_{2}} \mathrm{CH}-\mathrm{N}^{+}\right), 2.27(\mathrm{~m}, J=7.3 \mathrm{~Hz}, J=7.0 \mathrm{~Hz}$, $2 \mathrm{H}, 2 \mathrm{CH}-\mathrm{N}^{+}$of cyclohexyl ring), $2.31(\mathrm{~s}, J=7.1 \mathrm{~Hz}, 6 \mathrm{H})$, $2 \mathrm{CH}_{3} 6.96\left(\mathrm{~d}, J=6.4 \mathrm{~Hz}, 4 \mathrm{H}, \mathrm{C}-\mathrm{H}\right.$ of $\left.\mathrm{C}_{6} \mathrm{H}_{4}-\mathrm{OCH}_{3}-p\right), 7.13(\mathrm{~d}, J$ $=7.3 \mathrm{~Hz}, 4 \mathrm{H}, \mathrm{C}-\mathrm{H}$ of $\left.\mathrm{C}_{6} \mathrm{H}_{4}-\mathrm{OCH}_{3}-p\right), 7.17-7.35(\mathrm{~m}, 10 \mathrm{H}, 2 \mathrm{CO}-$ $\mathrm{Ar}-\mathrm{H}), 7.49-7.81(\mathrm{~m}, J=5.9 \mathrm{~Hz}, 10 \mathrm{H}, 2 \mathrm{Ar}-\mathrm{H}), 8.05$ (d, $J=$ $5.6 \mathrm{~Hz}, 2 \mathrm{H}, 2 \mathrm{CH}$ of pyridinium ring), 8.12 (d.d, $J=6.4 \mathrm{~Hz}, 2 \mathrm{H}$, $2 \mathrm{CH}$ of pyridinium ring), 8.15 (d.d, $J=7.1 \mathrm{~Hz}, 2 \mathrm{H}, 2 \mathrm{CH}$ of pyridinium ring), $8.92(\mathrm{~d}, J=7.3 \mathrm{~Hz}, 2 \mathrm{H}, 2 \mathrm{CH}$ of pyridinium ring); ${ }^{13} \mathrm{C}-\mathrm{NMR}\left(\mathrm{DMSO}-d_{6}\right) \delta / \mathrm{ppm}=24.4,58.0,99.4,114.5$, 116.2 , 124.5, 127.9, 128.5, 128.6, 128.9, 130.2, 131.2, 132.5, 134.5, 143.2, 143.3, 145.8, 147.1, 148.3, 188.7.; MS: $(\mathrm{m} / \mathrm{z}, \%)$ $977\left(\mathrm{M}^{+},-2 \mathrm{Br}^{-}, 93 \%\right), 901$ (47\%), 825 (29\%), 760 (34\%), 669 (59\%), 695 (81\%), 667 (57\%), 639 (55\%), 555 (100\%), 471 (23\%), 395 (76\%), 319 (16\%), 269 (81\%), 258 (68\%), 246 (64\%), 181 (25\%), 116 (89\%), 76 (68\%). Anal. calcd for $\mathrm{C}_{62}$ $\mathrm{H}_{52} \mathrm{~N}_{6} \mathrm{O}_{2} \mathrm{~S}_{2} \mathrm{Br}_{2}$ (1137): C, 76.20; H, 5.36; N, 8.60\%. Found: C, $76.23 ; \mathrm{H}, 5.36 ; \mathrm{N}, 8.60 \%$.

1,1'-[(Cyclohexane-1,4-diyl)bis(2-(Z)-(5-benzoyl-3-(4-nitrophenyl)1,3,4-thidiazol-2(3H)-ylidene)(phenyl)methyl)]bis-pyridinium dibromide (12c). Yield 87\%; reddish brown crystals; m.p. $=253-$ $254{ }^{\circ} \mathrm{C}$; IR (KBr): $v / \mathrm{cm}^{-1}=3002(\mathrm{Ar}-\mathrm{CH}), 2922\left(\mathrm{CH}_{2}\right), 1737(\mathrm{C}=$ O), $1568(\mathrm{C}=\mathrm{N}) ;{ }^{1} \mathrm{H}-\mathrm{NMR}\left(\mathrm{CHCl}_{3}\right) \delta / \mathrm{ppm}=1.42(\mathrm{~d}, J=7.3 \mathrm{~Hz}$, $\left.8 \mathrm{H}, 4 \underline{\mathrm{CH}_{2}} \mathrm{CH}-\mathrm{N}^{+}\right), 2.26\left(\mathrm{~m}, J=7.6 \mathrm{~Hz}, 2 \mathrm{H}, 2 \underline{\mathrm{CH}}-\mathrm{N}^{+}\right.$of cyclohexyl ring), $2.31\left(\mathrm{~s}, J=6.4 \mathrm{~Hz}, 6 \mathrm{H}, 2 \mathrm{CH}_{3}\right), 7.33-7.91(\mathrm{~m}$, $20 \mathrm{H}, 4 \mathrm{Ar}-\mathrm{H}$ ), 7.91 (d, $J=6.9 \mathrm{~Hz}, 4 \mathrm{H}, \mathrm{C}-\mathrm{H}$ of $\left.\mathrm{C}_{6} \mathrm{H}_{4}-\mathrm{NO}_{2}-p\right), 8.05$ (d, 
$J=6.8 \mathrm{~Hz}, 2 \mathrm{H}, 2 \mathrm{CH}$ of pyridinium ring), 8.12 (d.d, $J=6.5 \mathrm{~Hz}, 2 \mathrm{H}$, $2 \mathrm{CH}$ of pyridinium ring), 8.15 (d.d, $J=6.8 \mathrm{~Hz}, 2 \mathrm{H}, 2 \mathrm{CH}$ of pyridinium ring), 8.28 (d, $J=6.5 \mathrm{~Hz}, 4 \mathrm{H}, \mathrm{C}-\mathrm{H}$ of $\left.\mathrm{C}_{6} \mathrm{H}_{4}-\mathrm{NO}_{2}-p\right), 8.92$ (d, $J=7.3 \mathrm{~Hz}, 2 \mathrm{H}, 2 \mathrm{CH}$ of pyridinium ring); ${ }^{13} \mathrm{C}-\mathrm{NMR}$ (DMSO- $d_{6}$ ) $\delta / \mathrm{ppm}=24.5,58.2$, 99.4, 115.5, 116.4 , 124.5, 127.9, 128.7, 128.9, 129.9, 131.2, 132.2, 132.5, 134.5, 143.2 , 143.5, 145.8, 147.2, 148.4, 188.8; MS: (m/z, \%) $1039\left(\mathrm{M}^{+},-2 \mathrm{Br}^{-}, 43 \%\right), 993$ (87\%), 947 (39\%), 871 (57\%), 795 (89\%), 691 (81\%), 587 (57\%), 503 (55\%), 421 (100\%), 333 (53\%), 245 (16\%), 167 (26\%), 89 (89\%), 49 (68\%). Anal. calcd for $\mathrm{C}_{60} \mathrm{H}_{46} \mathrm{~N}_{8} \mathrm{O}_{6} \mathrm{~S}_{2} \mathrm{Br}_{2}$ (1199): C, 69.35; H, 4.46; N, 10.78\%. Found: C, 69.37; H, 4.48; N, 10.80\%.

\section{General procedure for generation of bis-dimethine cyanine dyes 6,9 and $11 \mathrm{a}-\mathrm{c}$}

Pathway 1. To a suspension solution of potassium hydroxide (0.56 gm, $5 \mathrm{mmol})$ in DMF $(30 \mathrm{ml})$, 2-benzyl-1-(4bromocyclohexy)pyridine-1-ium salt (1.16 gm, $2 \mathrm{mmol})$ was added and then two moles of phenyl isothiocyanate $(1.07 \mathrm{gm}, 4$ $\mathrm{mmol}$ ) was added. The solution was stirred nightly at chamber temperature. After that, the reaction mixture was treated with alcoholic solution of ethyl bromoacetate and/or phenacyl bromide and/or three different aryl hydrazones $(4 \mathrm{mmol})$. The mixture was then stirred for about $6 \mathrm{~h}$ at room temperature. The solution was poured onto a specific amount of ice-cold water. This was followed by acidification using dilute $\mathrm{HCl}$ until the environment became acidic to yield solid products 6, 9 and 11ac, which were filtered, washed with chilled water. The drug was left to dry and recrystallized with aqueous absolute ethanol to give compounds 6, 9 and 11a-c.

Pathway 2. To an ethanolic solution, (1.70 gm, $2 \mathrm{mmol})$ of compound 3 reacted with two moles $(4 \mathrm{mmol})$ of ethyl bromoacetate and/or phenacyl bromide and/or three different aryl hydrazones, respectively. The reaction contents were stirred for about $6 \mathrm{~h}$ at $25{ }^{\circ} \mathrm{C}$. The solution was poured into a beaker containing a crushed ice-cold water. This was followed by acidification of the reaction contents using dilute $\mathrm{HCl}$ until the solution was neutralized to afford solid products 6,9 and 11a-c, which were filtered, washed with chilled water, dried and recrystallized with aqueous ethanol to obtain compounds $\mathbf{6}, 9$ and 11a-c.

1,1'-[(Cyclohexan-1,4-diyl)bis(2-(Z)-2((2-ethoxy-2-oxoethyl)thio)1-phenyl-2-(phenylamino)vinyl)]bis-pyridinium dibromide (6). Yield 47\%; yellow powder; m.p. $=222-223{ }^{\circ} \mathrm{C}$; IR $(\mathrm{KBr}): v / \mathrm{cm}^{-1}$ $=3323(\mathrm{NH}), 3009(\mathrm{Ar}-\mathrm{CH}), 2922\left(\mathrm{CH}_{2}\right), 1730(\mathrm{C}=\mathrm{O}), 1569(\mathrm{C}=$ $\mathrm{N}) ;{ }^{1} \mathrm{H}-\mathrm{NMR}\left(\mathrm{CHCl}_{3}\right) \delta / \mathrm{ppm}=1.31\left(\mathrm{t}, J=7.0 \mathrm{~Hz}, 6 \mathrm{H}, 2 \mathrm{CH}_{3}\right), 1.40$ $\left(\mathrm{d}, J=5.8 \mathrm{~Hz}, 8 \mathrm{H}, 4 \underline{\mathrm{CH}_{2}} \mathrm{CH}-\mathrm{N}^{+}\right), 2.26(\mathrm{~m}, J=6.3 \mathrm{~Hz}, 2 \mathrm{H}$, $2 \underline{\mathrm{CH}}-\mathrm{N}^{+}$of cyclohexyl ring), $3.23(\mathrm{~s}, J=5.7 \mathrm{~Hz}, 4 \mathrm{H}$, $\left.2 \mathrm{~S} \mathrm{CH}_{2} \mathrm{COO}\right), 4.30\left(\mathrm{q}, J=5.4 \mathrm{~Hz}, 4 \mathrm{H}, 2 \mathrm{CH}_{2}\right), 7.32-7.81(\mathrm{~m}, 20 \mathrm{H}$, $4 \mathrm{Ar}-\mathrm{H}$ ), 8.02 (d, $J=5.7 \mathrm{~Hz}, 2 \mathrm{H}, 2 \mathrm{CH}$ of pyridinium ring), 8.10 (d.d, $J=7.2 \mathrm{~Hz}, 2 \mathrm{H}, 2 \mathrm{CH}$ of pyridinium ring), 8.13 (d.d, $J=$ $7.0 \mathrm{~Hz}, 2 \mathrm{H}, 2 \mathrm{CH}$ of pyridinium ring), $8.82(\mathrm{~d}, J=8.0 \mathrm{~Hz}, 2 \mathrm{H}, 2 \mathrm{CH}$ of pyridinium ring), $12.90(\mathrm{~s}, 2 \mathrm{H}, 2 \mathrm{NH}) ;{ }^{13} \mathrm{C}-\mathrm{NMR}$ (DMSO- $d_{6}$ ) $\delta / \mathrm{ppm}=14.1,24.5,26.5,58.2,60.6,115.6,116.9,124.5,127.9$, $128.7,128.9,129.9,132.2,132.8,132.9,134.6,143.5,143.7$, 145.8, 147.2, 148.4, 170.8; MS: $(\mathrm{m} / \mathrm{z}, \%) 865\left(\mathrm{M}^{+}+2,-2 \mathrm{Br}^{-}\right.$, $76 \%), 820$ (27\%), 775 (29\%), 747 (87\%), 719 (89\%), 673 (31\%),
627 (57\%), 551 (45\%), 475 (12\%), 449 (53\%), 423 (16\%), 335 (26\%), 247 (100\%), 169 (34\%), 91 (53\%), 51 (63\%). Anal. calcd for $\mathrm{C}_{60} \mathrm{H}_{46} \mathrm{~N}_{8} \mathrm{O}_{6} \mathrm{~S}_{2} \mathrm{Br}_{2}$ (1023): C, 72.36; $\mathrm{H}, 3.61 ; \mathrm{N}, 6.49 \%$. Found: $\mathrm{C}, 72.37 ; \mathrm{H}, 3.64 ; \mathrm{N}, 6.52 \%$.

1,1'-[(Cyclohexane-1,4-diyl)bis(2-(Z)-2((2-oxo-2-phenylethyl)thio)1-phenyl-2-(phenylamine)vinyl)]bis-pyridinium dibromide (9). Yield $75 \%$; yellow powder; m.p. $=206{ }^{\circ} \mathrm{C}$; IR $(\mathrm{KBr}): v / \mathrm{cm}^{-1}=3322$ (NH), 3002 (Ar-CH), $2922\left(\mathrm{CH}_{2}\right), 1728(\mathrm{C}=\mathrm{O}), 1569(\mathrm{C}=\mathrm{N}) ;{ }^{1} \mathrm{H}-$ NMR $\left(\right.$ DMSO- $\left.d_{6}\right) \delta / \mathrm{ppm}=1.42(\mathrm{~d}, J=7.1 \mathrm{~Hz}, 8 \mathrm{H}$, $\left.4 \underline{\mathrm{CH}_{2}} \mathrm{CH}-\mathrm{N}^{+}\right), 2.26\left(\mathrm{~m}, J=7.6 \mathrm{~Hz}, 2 \mathrm{H}, 2 \underline{\mathrm{CH}}-\mathrm{N}^{+}\right.$of cyclohexyl ring), $2.51\left(\mathrm{~s}, J=7.2 \mathrm{~Hz}, 4 \mathrm{H}, 2 \mathrm{~S} \mathrm{CH}_{2} \mathrm{CO}\right), 7.22-7.34(\mathrm{~m}$, 20H, 4Ar-H), 7.43-74 (m, 10H, 2Ar-H), 8.05 (d, $J=7.4 \mathrm{~Hz}, 2 \mathrm{H}$, $2 \mathrm{CH}$ of pyridinium ring), 8.12 (d.d, $J=7.1 \mathrm{~Hz}, 2 \mathrm{H}, 2 \mathrm{CH}$ of pyridinium ring), 8.14 (d.d, $J=7.3 \mathrm{~Hz}, 2 \mathrm{H}, 2 \mathrm{CH}$ of pyridinium ring), $8.83(\mathrm{~d}, J=5.8 \mathrm{~Hz}, 2 \mathrm{H}, 2 \mathrm{CH}$ of pyridinium ring), 11.92 (s, $J=$ $6.4 \mathrm{~Hz}, 2 \mathrm{H}, 2 \mathrm{NH}) ;{ }^{13} \mathrm{C}-\mathrm{NMR}\left(\mathrm{CHCl}_{3}\right) \delta / \mathrm{ppm}=24.2,26.8,58.2$, 61.6, 116.9, 117.3, 124.5, 128.0, 128.7, 128.9, 129.9, 131.4, 132.8, 132.9, 134.6, 143.7, 143.5, 145.8, 147.3, 148.5, 177.2.; MS: $(\mathrm{m} / \mathrm{z}, \%)$ $927\left(\mathrm{M}^{+},-2 \mathrm{Br}, 39 \%\right), 852$ (27\%), 775 (29\%), 747 (87\%), 718 (89\%), 675 (31\%), 627 (57\%), 552 (45\%), 475 (12\%), 449 (53\%), 423 (16\%), 335 (26\%), 247 (100\%), 170 (34\%), 90 (53\%), 50 (63\%). Anal. calcd for $\mathrm{C}_{60} \mathrm{H}_{46} \mathrm{~N}_{8} \mathrm{O}_{6} \mathrm{~S}_{2} \mathrm{Br}_{2}$ (1087): C, 77.72; $\mathrm{H}, 5.87 ; \mathrm{N}$, 6.04\%. Found: C, 77.72; H, 5.87; N, 6.04\%.

2-((Z)-2-(E)-1-(2-(4-methoxyphenyl)hydrazono)-2-oxo-2-phenylethylthio)-1-phenyl-2-(phenylamino)vinyl)-1-(4-(2-((Z)-2-((Z)-pyridin1-ium)cyclohexyl)bis-pyridinium)dibromide (11a). Yield 54\%; red powder; m.p. $=235{ }^{\circ} \mathrm{C}$; IR (KBr): $v / \mathrm{cm}^{-1}=3312-3324(2 \mathrm{NH})$, 3004 (Ar-CH), $2925\left(\mathrm{CH}_{2}\right), 1695(\mathrm{C}=\mathrm{O}), 1570(\mathrm{C}=\mathrm{N}) ;{ }^{1} \mathrm{H}-\mathrm{NMR}$ $\left(\mathrm{CHCl}_{3}\right) \delta / \mathrm{ppm}=1.71\left(\mathrm{~d}, J=7.3 \mathrm{~Hz}, 8 \mathrm{H}, 4 \mathrm{CH}_{2} \mathrm{CH}-\mathrm{N}^{+}\right), 2.26$ $\left(\mathrm{m}, J=7.1 \mathrm{~Hz}, 2 \mathrm{H}, 2 \underline{\mathrm{CH}}-\mathrm{N}^{+}\right.$of cyclohexyl ring), $3.80(\mathrm{~s}, J=$ $\left.6.7 \mathrm{~Hz}, 3 \mathrm{H}, 2 \mathrm{O} \mathrm{CH}_{3}\right), 6.73-7.10\left(\mathrm{~m}, 8 \mathrm{H}, 2 \mathrm{C}_{6} \mathrm{H}_{4}-\mathrm{OCH}_{3}-p\right), 7.17-$ $7.52(\mathrm{~m}, 20 \mathrm{H}, 4 \mathrm{Ar}-\mathrm{H}), 7.53-74(\mathrm{~m}, 10 \mathrm{H}, 2 \mathrm{Ar}-\mathrm{H}), 8.05$ (d, $J=5.8 \mathrm{~Hz}$, $2 \mathrm{H}, 2 \mathrm{CH}$ of pyridinium ring), 8.12 (d.d, $J=6.1 \mathrm{~Hz}, 2 \mathrm{H}, 2 \mathrm{CH}$ of pyridinium ring), 8.14 (d.d, $J=8.0 \mathrm{~Hz}, 2 \mathrm{H}, 2 \mathrm{CH}$ of pyridinium ring), 8.83 (d, $J=7.8 \mathrm{~Hz}, 2 \mathrm{H}, 2 \mathrm{CH}$ of pyridinium ring), $10.74(\mathrm{~s}, J$ $=7.0 \mathrm{~Hz}, 2 \mathrm{H}, 2 \mathrm{NH}), 11.61(\mathrm{~s}, J=7.1 \mathrm{~Hz}, 2 \mathrm{H}, 2 \mathrm{NH}) ;{ }^{13} \mathrm{C}-\mathrm{NMR}$ $\left(\mathrm{CHCl}_{3}\right) \delta / \mathrm{ppm}=33.5,27.0,54.2,115.1,117.3,122.4,125.4$, 127.1, 127.2, 127.9, 128.9, 128.3, 128.6, 129.2, 129.5, 133.6, 134.5, 136.4, 147.1, 158.3, 188.7; MS: ( $m / z, \%) 1195\left(\mathrm{M}^{+},-2 \mathrm{Br}^{-}, 74 \%\right)$, 1164 (27\%), 1133 (29\%), 1058 (87\%), 983 (89\%), 908 (31\%), 880 (57\%), 852 (45\%), 748 (12\%), 644 (53\%), 632 (16\%), 620 (26\%), 588 (100\%), 556 (34\%), 465 (53\%), 374 (63\%), 362 (21\%), 286 (81\%), 210 (63\%), 132 (34\%), 54 (36\%). Anal. calcd for $\mathrm{C}_{74} \mathrm{H}_{66}$ $\mathrm{N}_{8} \mathrm{O}_{4} \mathrm{~S}_{2} \mathrm{Br}_{2}$ (1355): C, 74.35; H, 5.56; N, 9.37\%. Found: C, 74.38; H, $5.57 ; \mathrm{N}, 9.40 \%$.

2-((Z)-2-(E)-1-(2-(4-methylphenyl)hydrazono)-2-oxo-2-phenylethylthio)-1-phenyl-2-(phenylamino)vinyl)-1-(4-(2-(Z)-2-((Z)-pyridin-1-ium)cyclohexyl)bis-pyridinium dibromide (11b). Yield 65\%; green powder; m.p. $=241-242{ }^{\circ} \mathrm{C}$; IR $(\mathrm{KBr}): \mathrm{v} / \mathrm{cm}^{-1}=3312-3324(2 \mathrm{NH})$, 3006 (Ar-CH), $2925\left(\mathrm{CH}_{2}\right), 1730(\mathrm{C}=\mathrm{O}), 1570(\mathrm{C}=\mathrm{N}) ;{ }^{1} \mathrm{H}-\mathrm{NMR}$ $\left(\right.$ DMSO- $\left.d_{6}\right) \delta / \mathrm{ppm}=1.53\left(\mathrm{~d}, J=7.3 \mathrm{~Hz}, 8 \mathrm{H}, 4 \underline{\mathrm{CH}_{2}} \mathrm{CH}-\mathrm{N}^{+}\right)$, $2.26\left(\mathrm{~m}, J=5.9 \mathrm{~Hz}, 2 \mathrm{H}, 2 \underline{\mathrm{CH}}-\mathrm{N}^{+}\right.$of cyclohexyl ring), $2.30(\mathrm{~s}, J=$ $\left.6.6 \mathrm{~Hz}, 3 \mathrm{H}, 2 \mathrm{CH}_{3}\right), 7.17-7.32(\mathrm{~m}, 20 \mathrm{H}, 4 \mathrm{Ar}-\mathrm{H}), 7.45(\mathrm{~d}, J=7.5 \mathrm{~Hz}$, $\left.4 \mathrm{H}, 2 \mathrm{C}_{6} \mathrm{H}_{4}-\mathrm{OCH}_{3}-p\right), 7.49\left(\mathrm{~d}, J=8.0 \mathrm{~Hz}, 4 \mathrm{H}, 2 \mathrm{C}_{6} \mathrm{H}_{4}-\mathrm{OCH}_{3}-p\right)$, 7.53-7.56 (m, 10H, 2Ar-H), $8.02(\mathrm{~d}, J=6.9 \mathrm{~Hz}, 2 \mathrm{H}, 2 \mathrm{CH}$ of pyridinium ring), 8.11 (d.d, $J=5.9 \mathrm{~Hz}, 2 \mathrm{H}, 2 \mathrm{CH}$ of pyridinium ring), 8.14 (d.d, $J=5.7 \mathrm{~Hz}, 2 \mathrm{H}, 2 \mathrm{CH}$ of pyridinium ring), 8.86 (d, $J=$ 
$5.8 \mathrm{~Hz}, 2 \mathrm{H}, 2 \mathrm{CH}$ of pyridinium ring), $10.75(\mathrm{~s}, J=5.9 \mathrm{~Hz}, 2 \mathrm{H}$, 2NH), $11.62(\mathrm{~s}, 6.8,2 \mathrm{H}, 2 \mathrm{NH}) ;{ }^{13} \mathrm{C}-\mathrm{NMR}\left(\mathrm{CHCl}_{3}\right) \delta / \mathrm{ppm}=24.5$, 58.2, 116.2, 117.2, 122.4, 125.4, 127.9, 128.6, 129.2, 131.2, 133.6, 134.5, 136.6, 140.0, 145.8, 147.1, 158.8, 187.7; MS: (m/z, \%) 1163 $\left(\mathrm{M}^{+},-2 \mathrm{Br}^{-}, 94 \%\right), 1148$ (37\%), 1133 (89\%), 1057 (26\%), 980 (38\%), 910 (69\%), 880 (59\%), 852 (75\%), 748 (42\%), 644 (55\%), 632 (66\%), 620 (90\%), 588 (100\%), 556 (35\%), 465 (24\%), 374 (13\%), 362 (22\%), 286 (86\%), 210 (64\%), 132 (33\%), 54 (29\%). Anal. calcd for $\mathrm{C}_{74} \mathrm{H}_{66} \mathrm{~N}_{8} \mathrm{O}_{2} \mathrm{~S}_{2} \mathrm{Br}_{2}$ (1323): C, 76.39; H, 5.75; N, 9.63\%. Found: C, 76.39; H, 5.75; N, 9.63\%.

2-((Z)-2-((E)-1-(2-(4-nitrophenyl)hydrazono)-2-oxo-2-phenylethylthio)-1-phenyl-2-(phenylamino)vinyl)-1-(4-(2-(Z)-2-((Z)-pyridin-1-ium)cyclohexyl)bis-pyridinium)dibromide (11c). Yield 65\%; green powder; m.p. $=195{ }^{\circ} \mathrm{C}$; IR $(\mathrm{KBr}): \mathrm{v} / \mathrm{cm}^{-1}=3332-3350(2 \mathrm{NH}), 3006$ (Ar-CH), $2925\left(\mathrm{CH}_{2}\right), 1732(\mathrm{C}=\mathrm{O}), 1570(\mathrm{C}=\mathrm{N})$; ${ }^{1} \mathrm{H}-\mathrm{NMR}$ (DMSO$\left.d_{6}\right) \delta / \mathrm{ppm}=1.72\left(\mathrm{~d}, J=6.7 \mathrm{~Hz}, 8 \mathrm{H}, 4 \mathrm{CH}_{2} \mathrm{CH}-\mathrm{N}^{+}\right), 2.28(\mathrm{~m}, J=$ $6.4 \mathrm{~Hz}, 2 \mathrm{H}, 2 \underline{\mathrm{CH}}-\mathrm{N}^{+}$of cyclohexyl ring), 7.17-7.32 (m, 20H, 4Ar$\mathrm{H}), 7.47\left(\mathrm{~d}, J=7.1 \mathrm{~Hz}, 4 \mathrm{H}, 2 \mathrm{C}_{6} \mathrm{H}_{4}-\mathrm{NO}-p\right), 7.52(\mathrm{~d}, J=7.9 \mathrm{~Hz}, 4 \mathrm{H}$, $\left.2 \mathrm{C}_{6} \mathrm{H}_{4}-\mathrm{NO}-p\right), 7.55-7.57(\overline{\mathrm{m}, 10 \mathrm{H}}, 2 \mathrm{Ar}-\mathrm{H}), 8.03(\mathrm{~d}, J=7.0 \mathrm{~Hz}, 2 \mathrm{H}$, $2 \mathrm{CH}$ of pyridinium ring), 8.12 (d.d, $J=6.8 \mathrm{~Hz}, 2 \mathrm{H}, 2 \mathrm{CH}$ of pyridinium ring), 8.15 (d.d, $J=6.3 \mathrm{~Hz}, 2 \mathrm{H}, 2 \mathrm{CH}$ of pyridinium ring), 8.84 (d, $J=5.6 \mathrm{~Hz}, 2 \mathrm{H}, 2 \mathrm{CH}$ of pyridinium ring), 10.74 (s, $J=$ $6.0 \mathrm{~Hz}, 2 \mathrm{H}, 2 \mathrm{NH}), 11.60(\mathrm{~s}, J=6.3 \mathrm{~Hz}, 2 \mathrm{H}, 2 \mathrm{NH}) ;{ }^{13} \mathrm{C}-\mathrm{NMR}\left(\mathrm{CHCl}_{3}\right)$ $\delta / \mathrm{ppm}=24.4,58.3,116.3,116.3,117.2,123.5,126.4,127.9,128.5$, 129.3, 132.0, 133.6, 134.3, 136.6, 140.1, 145.7, 147.2, 158.5, 187.3; MS: (m/z, \%) $1225\left(\mathrm{M}^{+},-2 \mathrm{Br}^{-}, 41 \%\right), 1179(17 \%), 1133$ (59\%), 1057 (66\%), 980 (72\%), 911 (54\%), 881 (60.3\%), 851 (74\%), 747 (32\%), 644 (19\%), 632 (36\%), 621 (32\%), 588 (100\%), 556 (95\%), 465 (48\%), 374 (75\%), 362 (12\%), 286 (14\%), 210 (24\%), 132 (36\%), 54 (47\%). Anal. calcd for $\mathrm{C}_{72} \mathrm{H}_{60} \mathrm{~N}_{10} \mathrm{O}_{6} \mathrm{~S}_{2} \mathrm{Br}_{2}$ (1385): C, 70.57; $\mathrm{H}$, 4.94; N, 11.43\%. Found: C, 70.58; H, 4.97; N, 11.46\%.

2-((Z)-(E)-4-oxo-3-phenyl-5-(porphyrin-2-ylmethylene)thiazolidin2-ylidene)(phenyl)(methyl)-1-(4-(2-((Z)-(E)-4-oxo-3-phenyl-5-(porphyrin2-ylmethylene)thiazolidin-2-ylidene(phenyl)(methyl)pyridin-1-ium-1yl)cyclohexyl)bis-pyridinium)dibromide (8). In a round bottom flask fitted with a reflux condenser, compound 7 (1 mmol, $0.93 \mathrm{gm}$ ) and porphyrin-2-carbaldehyde (0.002 mmol, $0.676 \mathrm{gm}$ ) were dissolved in $\mathrm{N}, \mathrm{N}$-dimethylformamide by heating for $24 \mathrm{~h}$ with magnetic stirring in presence of piperidine as a catalyst under nitrogen gas. The solution contents were heated gradually to $100{ }^{\circ} \mathrm{C}$. The reaction mixture was maintained at $100{ }^{\circ} \mathrm{C}$ for about $12 \mathrm{~h}$ and then raise the temperature was increased to $150{ }^{\circ} \mathrm{C}$ followed by continuous heating at this temperature for $12 \mathrm{~h}$. The reaction contents were observed using TLC. The contents were cooled and poured it onto ice-cold water. The solid was filtered and washed with cold water. The isolated solid 8 was purified by HPLC $\left(\mathrm{CHCl}_{3}\right.$ : hexane : $\left.\mathrm{NH}_{2} \mathrm{OH}, 10: 5: 0.5\right)$ as eluent.

Yield $43 \%$; violet crystals; m.p. $>300{ }^{\circ} \mathrm{C}$; IR $(\mathrm{KBr}): v / \mathrm{cm}^{-1}=$ 3312-3325 (4NH), 3123-3145 (2Ar-CH), $2930\left(\mathrm{CH}_{2}\right), 1692(\mathrm{C}=$ O), 1632-1634 $\left(\mathrm{C}=\mathrm{N}^{+}\right) ;{ }^{1} \mathrm{H}-\mathrm{NMR}\left(\mathrm{DMSO}-d_{6}\right) \delta / \mathrm{ppm}=1.41(\mathrm{~d}, J=$ $\left.7.3 \mathrm{~Hz}, 8 \mathrm{H}, 4 \mathrm{CH}_{2} \mathrm{CH}-\mathrm{N}^{+}\right), 2.28\left(\mathrm{~m}, J=7.1 \mathrm{~Hz}, 1 \mathrm{H}, \underline{\mathrm{CH}}-\mathrm{N}^{+}\right.$of cyclohexyl ring), 4.30 (s, $J=7.6 \mathrm{~Hz}, 4 \mathrm{H}, 4 \mathrm{CH}$ methine bridge of porphyrin ring), $5.62(\mathrm{~s}, J=5.5 \mathrm{~Hz}, 2 \mathrm{H}, 2 \mathrm{NH}), 6.24(\mathrm{~d}, J=7.0 \mathrm{~Hz}$, $4 \mathrm{H}, 4 \mathrm{CH}$ methine of pyrrole ring of porphyrin ring), $6.46(\mathrm{~s}, J=$ $7.3 \mathrm{~Hz}, 2 \mathrm{H}, 2 \mathrm{CH}$ methine of pyrrole ring of porphyrin ring), 6.66 (d, $J=7.1 \mathrm{~Hz}, 2 \mathrm{H}, 2 \mathrm{Ph}-\mathrm{C}=\underline{\mathrm{CH}}$-porphyrin), $6.98(\mathrm{~s}, J=5.9 \mathrm{~Hz}$, $4 \mathrm{H}, 4 \mathrm{CH}$ methine bridge of porphyrin ring), 7.84 (d, $J=5.8 \mathrm{~Hz}$,
$2 \mathrm{H}, 2 \mathrm{CH}$ methine of pyrrole ring of porphyrin ring), 7.10-7.19 (m, 10H, 2Ar-H), 7.29 (d, $J=6.7 \mathrm{~Hz}, 1 \mathrm{H}, \mathrm{CH}$ of pyridinium ring), 7.30-7.43 (m, 4H, Ar-H), 7.84 (d, $J=5.3 \mathrm{~Hz}, 2 \mathrm{H}, 2 \mathrm{CH}$ methine of pyrrole ring of porphyrin ring), $8.05(\mathrm{~d}, J=6.1 \mathrm{~Hz}, 1 \mathrm{H}, \mathrm{CH}$ of pyridinium ring), 8.11 (d.d, $J=7.6 \mathrm{~Hz}, 1 \mathrm{H}, \mathrm{CH}$ of pyridinium ring), 8.14 (d.d, $J=7.0 \mathrm{~Hz}, 1 \mathrm{H}, \mathrm{CH}$ of pyridinium ring), 8.92 (d, $J$ $=5.7 \mathrm{~Hz}, 1 \mathrm{H}, \mathrm{CH}$ of pyridinium ring), $12.89(\mathrm{~s}, J=5.9 \mathrm{~Hz}, 2 \mathrm{H}$, $2 \mathrm{NH}$ ); ${ }^{13} \mathrm{C}-\mathrm{NMR}\left(\mathrm{DMSO}-d_{6}\right) \delta / \mathrm{ppm}=33.5,58.0,109.0,109.8$, 112.1 , 114.8, 122.9, 127.2, 127.9, 128.0, 128.3, 128.6, 129.8, 130.9, 132.7, 133.5, 135.5, 140.0, 145.8, 146.9, 147.1, 148.4, 180.6; MS: $(\mathrm{m} / \mathrm{z}, \%) 1413\left(\mathrm{M}^{+}+2,-2 \mathrm{Br}, 67 \%\right), 1102(73 \%), 793$ (39\%), 780 (47\%), 767 (81\%), 755 (95\%), 743 (100\%), 715 (17\%), 687 (28\%), 597 (72\%), 507 (62\%), 463 (39\%), 419 (54\%), 343 (71\%), 253 (38\%), 175 (84\%), 97 (17\%), 57 (64\%). Anal. calcd for $\mathrm{C}_{51} \mathrm{H}_{44} \mathrm{~N}_{6} \mathrm{Br}_{2}$ (1571): C, 76.57; H, 4.71; N, 11.91\%. Found: C, 76.59; H, 4.73; N, 11.94\%.

1,1'-[(cyclohexane-1,4-diyl)bis(2-(Z)-(5-hydrazinyl-3-pheny-1,2,3thiadiazol-2(3H)-ylidene) (phenyl)methyl)]bis-pyridinium dibromide (14). Pathway 1. A mixture of compound 3 (1 $\mathrm{mmol}$, $0.85 \mathrm{gm}$ ) and thiocarbohydrazide ( $2 \mathrm{mmol}, 0.212 \mathrm{gm}$ ) in $N, N$ dimethylformamide in the presence of few drops of triethylamine was refluxed for $4 \mathrm{~h}$. The reaction contents were filtered while hot to remove any unreacted material. The solution was evaporated under vacuum. The solid product was purified with absolute ethanol to produce compound 14.

Pathway 2. A solution of compound 15 (1 mmol, $0.899 \mathrm{gm})$ in $25 \mathrm{ml} \mathrm{N}, \mathrm{N}$-dimethylformamide in the presence of few droplets of triethylamine was refluxed for $6 \mathrm{~h}$. The colour of the reaction mixture varied from deep yellow to red then to brown at the end of the reaction. The reaction contents were filtered while hot to remove the unreacted material. The reaction mixture was evaporated under vacuum. The solid product was recrystallized using a proper solvent like absolute ethanol to give compound 14.

Yield 64\%; brown powder; m.p. $=215-216{ }^{\circ} \mathrm{C}$; IR $(\mathrm{KBr})$ : $v / \mathrm{cm}^{-1}=3174-3325\left(2 \mathrm{NHNH}_{2}\right), 3114-3025(2 \mathrm{Ar}-\mathrm{CH}), 2931$ $\left(\mathrm{CH}_{2}\right), 1574-1578\left(\mathrm{C}=\mathrm{N}^{+}\right) ;{ }^{1} \mathrm{H}-\mathrm{NMR}\left(\mathrm{DMSO}-d_{6}\right) \delta / \mathrm{ppm}=1.42(\mathrm{~d}$, $\left.J=6.7 \mathrm{~Hz}, 8 \mathrm{H}, 4 \mathrm{CH}_{2} \mathrm{CH}-\mathrm{N}^{+}\right), 2.27(\mathrm{~m}, J=7.0 \mathrm{~Hz}, 1 \mathrm{H}$, $\underline{\mathrm{CH}}-\mathrm{N}^{+}$of cyclohexyl ring), $3.81\left(\mathrm{~s}, J=6.8 \mathrm{~Hz}, 4 \mathrm{H}, 2 \mathrm{NH}_{2}\right), 6.87-$ $\overline{6.94}(\mathrm{~m}, 10 \mathrm{H}, 2 \mathrm{Ar}-\mathrm{H}), 7.21-7.39$ (m, 10H, 2Ar-H), 78.05 (d, $J=$ $4.8 \mathrm{~Hz}, 1 \mathrm{H}, \mathrm{CH}$ of pyridinium ring), 8.00 (d.d, $J=6.2 \mathrm{~Hz}, 1 \mathrm{H}, \mathrm{CH}$ of pyridinium ring), 8.13 (d.d, $J=7.3 \mathrm{~Hz}, 1 \mathrm{H}, \mathrm{CH}$ of pyridinium ring), $8.78(\mathrm{~d}, J=6.8 \mathrm{~Hz}, 1 \mathrm{H}, \mathrm{CH}$ of pyridinium ring), $8.80(\mathrm{~s}, J=$ $6.7 \mathrm{~Hz}, 2 \mathrm{H}, 2 \mathrm{NH}) ;{ }^{13} \mathrm{C}-\mathrm{NMR}\left(\mathrm{DMSO}-d_{6}\right) \delta / \mathrm{ppm}=25.1,35.5,58.2$, 107.2 , 109.7, 112.8, 115.2, 122.1, 127.5, 127.8, 128.1, 128.6, $129.1,129.8,131.9,132.7,134.5,135.5,140.4,145.4,146.9$, 147.3, 148.5; MS: (m/z, \%) $865\left(\mathrm{M}^{+},-2 \mathrm{Br}, 24 \%\right), 834$ (29\%), 803 (62\%), 761 (62\%), 687 (32\%), 602 (15\%), 516 (100\%), 440 (74\%), 365 (92\%), 353 (37\%), 342 (56\%), 263 (81\%), 185 (52\%), 175 (45\%), 97 (37\%), 57 (32\%). Anal. calcd for $\mathrm{C}_{46} \mathrm{H}_{44} \mathrm{~N}_{10} \mathrm{~S}_{4} \mathrm{Br}_{2}$ (1025): C, 61.44; H, 5.60; N, 18.69\%. Found: C, 61.44; H, 5.60; N, $18.69 \%$

2-((Z)-2-((E)-hydrazinyl(hydrazono)methyl)thio)-1-phenyl-2-(phenylamino)vinyl)-1-(4-(2-((Z)-2-(((Z)-hydrazinyl(hydrazono)methyl)thio)1-phenyl-2-(phenylamino)vinyl)-bis-pyridinium)dibromide (15). In a round bottom flask fitted with a reflux water condenser, compound 3 (1 mmol, $0.85 \mathrm{gm}$ ) and thiocarbohydrazide 
( $2 \mathrm{mmol}, 0.212 \mathrm{gm}$ ) were refluxed in $20 \mathrm{ml}$ absolute ethanol in the presence of freshly fused potassium carbonate. The reaction mixture was stirred for $30 \mathrm{~min}$ until all materials were dissolved. Then, the reflux was continued for about $3.5 \mathrm{~h}$. The solution was cooled in ice-salt bath until it reached $0{ }^{\circ} \mathrm{C}$. The product was then filtered using a pump, washed with some water, drained well, and then wash with $25 \mathrm{ml}$ ethanol and dried in air. The crude product was recrystallized using methanol. The yield of the formed compound $\mathbf{1 5}$ was 75\%.

Yield 75\%; red powder; m.p. $=256{ }^{\circ} \mathrm{C}$; IR $(\mathrm{KBr}): v / \mathrm{cm}^{-1}=$ 3174-3325 (4NH, 4NH ${ }_{2}$ ), 3115-3029 (4Ar-CH), $2932\left(\mathrm{CH}_{2}\right), 1575-$ $1579\left(\mathrm{C}=\mathrm{N}^{+}\right) ;{ }^{1} \mathrm{H}-\mathrm{NMR}\left(\mathrm{DMSO}-d_{6}\right) \delta / \mathrm{ppm}=1.43(\mathrm{~d}, J=7.4 \mathrm{~Hz}$, $\left.8 \mathrm{H}, 4 \underline{\mathrm{CH}_{2}} \mathrm{CH}-\mathrm{N}^{+}\right), 2.25\left(\mathrm{~m}, J=7.3 \mathrm{~Hz}, 1 \mathrm{H}, \underline{\mathrm{CH}}-\mathrm{N}^{+}\right.$of cyclohexyl ring), $3.81\left(\mathrm{~s}, J=7.8 \mathrm{~Hz}, 4 \mathrm{H}, 2 \mathrm{NH} \mathrm{NH}_{2}\right), 4.2(\mathrm{~s}, J=$ $\left.7.1 \mathrm{~Hz}, 4 \mathrm{H}, \mathrm{C}=\mathrm{N}-\mathrm{NH}_{2}\right), 6.87-6.94(\mathrm{~m}, 10 \mathrm{H}, \overline{2 \mathrm{Ar}-\mathrm{H}}), 7.21-7.39$ $(\mathrm{m}, 10 \mathrm{H}, 2 \mathrm{Ar}-\mathrm{H}), 7.85(\mathrm{~d}, J=7.3 \mathrm{~Hz}, 1 \mathrm{H}, \mathrm{CH}$ of pyridinium ring), 8.02 (d.d, $J=7.0 \mathrm{~Hz}, 1 \mathrm{H}, \mathrm{CH}$ of pyridinium ring), 8.12 (d.d, $J=$ $7.5 \mathrm{~Hz}, 1 \mathrm{H}, \mathrm{CH}$ of pyridinium ring), 8.76 (d, $J=7.0 \mathrm{~Hz}, 1 \mathrm{H}, \mathrm{CH}$ of pyridinium ring), $8.80\left(\mathrm{~s}, J=6.8 \mathrm{~Hz}, 2 \mathrm{H}, 2 \underline{\mathrm{NH}} \mathrm{NH}_{2}\right), 10.62(\mathrm{~s}$, $J=6.4 \mathrm{~Hz}, 2 \mathrm{H}, 2 \underline{\mathrm{NH}}-\mathrm{Ph}) ;{ }^{13} \mathrm{C}-\mathrm{NMR}\left(\mathrm{DMSO}-d_{6}\right) \delta / \mathrm{ppm}=25.2$, 59.3, 106.2, 109.1, 112.7, 115.3, 122.2 , 127.7, 127.5, 128.2, 128.4, 129.2 , 129.7, 131.4, 132.7, 134.5, 135.4, 141.8, 145.4, 146.9, 147.3, 151.0; MS: $(\mathrm{m} / \mathrm{z}, \%) 899\left(\mathrm{M}^{+},-2 \mathrm{Br}, 56 \%\right), 868$ (46\%), 837 (32\%), 761 (62\%), 685 (32\%), 601 (90\%), 517 (100\%), 441 (25\%), 365 (78\%), 353 (47\%), 341 (19\%), 263 (80\%), 185 (51\%), 175 (44\%), 97 (37\%), 57 (64\%). Anal. calcd for $\mathrm{C}_{46} \mathrm{H}_{50} \mathrm{~N}_{12} \mathrm{~S}_{4} \mathrm{Br}_{2}$ (1059): C, 55.53; H, 5.07; N, 16.89\%. Found: C, 55.50; H, 5.04; N, $16.87 \%$.

2-((Z)-(3-methyl-5-(3-methyl-5-oxo-4,5-dihydro-1H-pyrazol-1-yl)3-phenyl-1,3 $\lambda^{4}$,4-thiadiazol-2(3H)-ylidene)(phenyl)methyl)-1-(4-2((Z)-(5-(3-methyl-5-oxo-4,5-dihydro-1H-pyrazol-1-yl)-3-phenyl-1,3,4thiadiazol-2(3H)-ylidene(phenyl)methyl)pyridin-1-ium-1-yl)cyclohexyl)bis-pyridinium dibromide (17). Yield 35\%; red powder; m.p. $=205-$ $20{ }^{\circ} \mathrm{C}$; IR (KBr): $v / \mathrm{cm}^{-1}=3115-3029$ (2Ar-CH), $2932\left(\mathrm{CH}_{2}\right), 1703$ $(2 \mathrm{C}=\mathrm{O}), 1575-1579\left(\mathrm{C}=\mathrm{N}^{+}\right) ;{ }^{1} \mathrm{H}-\mathrm{NMR}\left(\mathrm{DMSO}-d_{6}\right) \delta / \mathrm{ppm}=1.45(\mathrm{t}$, $\left.J=7.0 \mathrm{~Hz}, 8 \mathrm{H}, 4 \mathrm{CH}_{2} \mathrm{CH}-\mathrm{N}^{+}\right), 1.93\left(\mathrm{~s}, J=6.2 \mathrm{~Hz}, 6 \mathrm{H}, 2 \mathrm{CH}_{3}\right)$, $2.26\left(\mathrm{~m}, J=6.7 \mathrm{~Hz}, 1 \mathrm{H}, \underline{\mathrm{CH}}-\mathrm{N}^{+}\right.$of cyclohexyl ring),3.02 (s, $J=$ $\left.5.6 \mathrm{~Hz}, 4 \mathrm{H}, 2 \mathrm{CH}_{2}\right), 7.32-7.90(\mathrm{~m}, 20 \mathrm{H}, 2 \mathrm{Ar}-\mathrm{H}), 7.87$ (d, $J=5.4 \mathrm{~Hz}$, $1 \mathrm{H}, \mathrm{CH}$ of pyridinium ring), 8.04 (d.d, $J=5.7 \mathrm{~Hz}, 1 \mathrm{H}, \mathrm{CH}$ of pyridinium ring), 8.13 (d.d, $J=5.9 \mathrm{~Hz}, 1 \mathrm{H}, \mathrm{CH}$ of pyridinium ring), 8.75 (d, $J=6.4 \mathrm{~Hz}, 1 \mathrm{H}, \mathrm{CH}$ of pyridinium ring); ${ }^{13} \mathrm{C}-\mathrm{NMR}$ (DMSO$\left.d_{6}\right) \delta / \mathrm{ppm}=16.4,26.6,30.7,42.3,68.3,100.9,117.9,119.3,120.9$, 121.4, 122.4, 122.7, 129.5, 129.7, 137.6, 146.3, 147.4, 149.6, 150.3, 150.3, 155.7, 165.0; MS: ( $\mathrm{m} / \mathrm{z}, \%) 997\left(\mathrm{M}^{+},-2 \mathrm{Br}, 100 \%\right), 871(87 \%)$, 795 (42\%), 745 (28\%), 695 (39\%), 645 (84\%), 595 (18\%), 545 (45\%), 495 (61\%), 445 (47\%), 395 (59\%), 345 (80\%), 295 (12\%), 245 (51\%), 195 (74\%), 145 (81\%), 97 (17\%), 57 (60\%). Anal. calcd for $\mathrm{C}_{54} \mathrm{H}_{48}$ $\mathrm{N}_{10} \mathrm{O}_{2} \mathrm{~S}_{4} \mathrm{Br}_{2}$ (1157): C, 65.04; H, 4.85; N, 14.05\%. Found: C, 65.01; H, $4.81 ; \mathrm{N}, 14.02 \%$.

1,1'-[(Cyclohexane-1,4-diyl)bis(2-(Z)-(5-(3,5-dimethyl-1H-pyrazol1-yl)-3-phenyl-1,3,4-thiadiazol-2(3H)ylidene)(phenyl)methyl)]bispyridinium dibromide (18). Yield 96\%; red crystal; m. $p>300{ }^{\circ} \mathrm{C}$; IR (KBr): $v / \mathrm{cm}^{-1}=3117-3021(2 \mathrm{Ar}-\mathrm{CH}), 2931\left(\mathrm{CH}_{2}\right), 1575-$ $1579\left(\mathrm{C}=\mathrm{N}^{+}\right) ;{ }^{1} \mathrm{H}-\mathrm{NMR}\left(\mathrm{DMSO}-d_{6}\right) \delta / \mathrm{ppm}=1.40(\mathrm{~d}, J=7.1 \mathrm{~Hz}$, $\left.8 \mathrm{H}, 4 \mathrm{CH}_{2} \mathrm{CH}-\mathrm{N}^{+}\right), 2.20\left(\mathrm{~s}, J=6.4 \mathrm{~Hz}, 6 \mathrm{H}, 2 \mathrm{CH}_{3}\right), 2.26(\mathrm{~m}, J=$ $7.3 \mathrm{~Hz}, 1 \mathrm{H}, \underline{\mathrm{CH}}-\mathrm{N}^{+}$of cyclohexyl ring), $2.48(\mathrm{~s}, J=7.0 \mathrm{~Hz}, 6 \mathrm{H}$, $\left.2 \mathrm{CH}_{3}\right), 6.22(\mathrm{~s}, J=6.5 \mathrm{~Hz}, 2 \mathrm{H}, \mathrm{C}=\underline{\mathrm{CH}}), 7.21-7.84(\mathrm{~m}, 20 \mathrm{H}, 2 \mathrm{Ar}-$
$\mathrm{H}), 7.92(\mathrm{~d}, J=7.2 \mathrm{~Hz}, 1 \mathrm{H}, \mathrm{CH}$ of pyridinium ring), 8.06 (d.d, $J$ $=7.3 \mathrm{~Hz}, 1 \mathrm{H}, \mathrm{CH}$ of pyridinium ring), 8.15 (d.d, $J=7.6 \mathrm{~Hz}, 1 \mathrm{H}$, $\mathrm{CH}$ of pyridinium ring), $8.74(\mathrm{~d}, J=5.1 \mathrm{~Hz}, 1 \mathrm{H}, \mathrm{CH}$ of pyridinium ring); ${ }^{13} \mathrm{C}-\mathrm{NMR}\left(\mathrm{DMSO}-d_{6}\right) \delta / \mathrm{ppm}=13.2,13.5,85.2$, $16.4,100.9,110.0,112.3,113.3,117.2,120.0,121.4,122.7$, 124.0, 127.9, 128.6, 128.9. 129.7, 132.5, 136.3, 137.0, 147.3, 155.7, 165.0; MS: (m/z, \%) $929\left(\mathrm{M}^{+},-2 \mathrm{Br}, 97 \%\right), 853(67 \%), 778$ (92\%), 762 (48\%), 747 (84\%), 732 (84\%), 717 (58\%), 652 (89\%), 586 (61\%), 502 (47\%), 417 (59\%), 329 (80\%), 241 (12\%), 163 (51\%), 84 (72\%), 45 (61\%). Anal. calcd for $\mathrm{C}_{56} \mathrm{H}_{52} \mathrm{~N}_{10} \mathrm{~S}_{2} \mathrm{Br}_{2}$ (1157): C, 72.38; H, 5.65; N, 15.07\%. Found: C, 72.41; H, $5.68 ; \mathrm{N}, 15.09 \%$.

\section{Conclusion}

In this letter, we have developed an unprecedented, original two-component, one-pot approach for the synthesis of highly substituted methine cyanine dyes 3, 6, 7, 8, 9, 10, 11, 12, 14, 15, 17 and 18 via a non-isolable intermediate 2 and/or a key thiocarbamoyl intermediate $\mathbf{3}$ in moderate to high yield. The chemical structures of obtained potent and selective drugs were investigated by IR, ${ }^{1} \mathrm{H}-\mathrm{NMR},{ }^{13} \mathrm{C}-\mathrm{NMR}$, mass spectroscopy, UVvis and elemental analyses for $\mathrm{C} \mathrm{H} \mathrm{N}$ elements.

\section{Conflicts of interest}

The authors have no conflicts of interest to declare.

\section{Acknowledgements}

The authors would like to thank their institutions.

\section{Notes and references}

1 N. Matsumoto and M. Takahashi, Tetrahedron, 2002, 58, 10073.

2 A. A. Fadda, R. E. El-Mekawy and M. Taha Abdel Aa, Phosphorus, Sulfur, and Silicon and the Related Elements, 2015, $191(8), 1148$.

3 A. A. Fadda, S. I. El-Desoky, H. A. Etman, S. B. Bondock and M. A. Metwally, Sulfur Lett., 2002, 25, 199.

4 A. A. Fadda, S. I. El-Desoky, H. A. Etman, S. B. Bondock and M. A. Metwally, Sulfur Lett., 2003, 26, 127-137.

5 A. A. Fadda, M. R. Hala and M. E. A. Zaki, Molecules, 2000, 5, 701.

6 A. A. Fadda, M. E. A. Zaki, K. Samir and F. A. Amer, Phosphorus, Sulfur, and Silicon and the Related Elements, 2006, 181, 1815.

7 T. G. Deligeorgiev, D. A. Zaneva, H. E. Katerinopoulos and V. N. Kolev, Dyes Pigm., 1999, 41, 49.

8 I. M. Warner, S. A. Soper and L. B. McGown, Anal. Chem., 1996, 68, 73R.

9 T. Karatsu, M. Yanai, S. Yagai, J. Mizukami, T. Urano and A. Kitamura, J. Photochem. Photobiol., A, 2005, 170, 123.

10 H. Hoppe and N. S. Sariciftci, J. Mater. Sci., 2004, 19241945.

11 M. Matsui, Y. Hashimoto, K. Funabiki, J. Y. Jin, T. Yoshida and H. Minoura, Synth. Met., 2005, 148, 147. 
12 E. Delaey, F. van Laar, D. De Vos, A. Kamuhabwa, P. Jacobs and P. de Witte, J. Photochem. Photobiol., B, 2000, 55, 27.

13 H. Hilal and J. A. Taylor, Dyes Pigm., 2007, 75, 483.

14 H. J. Karlsson, M. H. Bergqvist, P. Lincoln and G. Westman, Bioorg. Med. Chem., 2004, 12, 2369.

15 Q. Li, Y. Kim, J. Namm, A. Kulkarni, G. R. Rosania, Y. H. Ahn and Y. T. Chang, Chem. Biol., 2006, 13, 615.

16 F. M. Hamer, The Cyanine Dyes and Related Compound; Interscience, New York, 1964.

17 A. A. Fadda, E. Abdel-Latif and R. E. El-Mekawy, Phosphorus, Sulfur, and Silicon and the Related Elements, 2008, 183(8), 1940.

18 A. A. Fadda, E. Abdel-Latif and R. E. El-Mekawy, Eur. J. Med. Chem., 2009, 44(3), 2223.

19 A. A. Fadda, E. Abdel-Latif and R. E. El-Mekawy, Pharmacol. Pharm., 2012, 3, 148.
20 R. E. El-Mekawy, Pharmacology, 2013, 4(11), 590.

21 H. M. Refat, A. A. Fadda, R. E. El-Mekawy and A. M. Sleat, Heterocycles, 2015, 19, 21-26.

22 S. Harusawa, K. Yoshida, C. Kojima, L. Araki and T. Kurihara, Tetrahedron, 2004, 60, 11911.

23 Y. B. Vibhute and M. A. Basser, Indian J. Chem., 2003, 42B, 202.

24 N. M. Hamada and E. M. Sharshira, Molecules, 2011, 16, 2304.

25 H. Musso, Tetrahedron, 1979, 35, 2843.

26 C. Reichardt, J. Phys. Org. Chem., 1995, 8, 761.

27 A. A. Fadda and R. E. El-Mekawy, Dyes Pigm., 2015, 118, 45.

28 A. A. Fadda and R. E. El-Mekawy, Dyes Pigm., 2013, 99, 512.

29 I. Timtcheva, V. Maximova, T. Deligeorgiev, D. Zanevac and I. Ivanovd, J. Photochem. Photobiol., A, 2000, 130, 7. 